\title{
TECHNICAL OWNERS AND THE PUBLIC UTILITIES BOARD
}

\author{
E.J. MCCOY*
}

Companies in the business of oil and gas exploration and development would not in common parlance, be referred to as "public utilities". Nonetheless, many enterprises involved in such undertakings find themselves increasingly regulated by the Public Utilities Board. They are known in the industry as "technical owners" because they are caught by the statutory definitions of "owner of a public utility". In this paper. the author traces the history of the legislation culminating in our present Public Utilities Board Act and Gas Utilities Act. Particular attention is paid to the political and economic events which underlie the evolution of those provisions which define and regulate technical owners.

Under the topic of jurisdiction, the author addresses the question of legislative authority and the extent to which the definitions of "gas utility" and "public utility" apply to facilities and activities of technical owners. The author concludes that while there may be some specific instances in which the statutes could not govern they are capable of very wide application.

The extent of jurisdiction is discussed with particular reference to the Board's power of control over securities, dispositions, encumbrances and mergers. This power is necessary for rate regulation since control of utility rates would be ineffective if utilities were unfettered in their financial dealings. Failure to obtain Board approval for such transactions can render the transaction unenforceable, although the courts have frequently avoided such harsh consequences in their interpretation of statutory limitations of contracts.

The statutes recognize that in some instances utility owners ought to be exempted from statutory regulation by providing for both "statutory exemptions" and "declaratory exemptions". Statutory exemptions are quite limited and apply only to specific forms of transaction. Declaratory exemptions, on the other hand, may exempt an owner from all the regulatory provision of the statutes. Unfortunately, Board orders granting declaratory exemptions often carry unclear and uncertain conditions subsequent. Thus, there is a great deal of uncertainty as to the future effectiveness of the order and as to the validity of any transaction.

Finally, the author discusses possible legislative amendments and gives practical advice to solicitors who must deal with the present legislation.

\section{INTRODUCTION}

During 1971, the Alberta Public Utilities Board (the Board) issued 25 financing and disposition approvals and no exemption orders ${ }^{1}$ pursuant to the Gas Utilities Act ${ }^{2}$ and the Public Utilities Board Act. ${ }^{3}$ During 1981, the Board issued 67 financing and disposition approvals plus 481 exemption orders. ${ }^{4}$ This increase can be attributed, in part, to a growing awareness among lawyers practising in the oil and gas field that their clients or other parties to a transaction come within the broad definitions of "owner of a gas utility" or "owner of a public utility" as set out in the statutes. Nevertheless, most of these parties would not, in common parlance, be characterized as owners of public utilities. Generally speaking, a public utility is taken to be an undertaking which supplies an essential commodity or service to the general public under conditions of natural or statutory monopoly within a given geographical area. The commodity or service is considered essential because it is a necessary element of the infrastructure around which a society is organized. Monopolistic conditions

* Counsel, Black and Company, Calgary.

1. Alberta Public Utilities Board Annual Report, 1971.

2. R.S.A. 1970 , c. 158.

3. R.S.A. 1970 , c. 302 .

4. Alberta Public Utilities Board Annual Report, 1981. 
prevail because it is generally conceded that society benefits if duplication of facilities can be avoided. "Necessity and monopoly are almost prerequisites of public utility status". ${ }^{5}$

Writing in $1961,{ }^{6}$ Professor James C. Bonbright qualified this simplistic view of what constitutes a public utility. He added "necessity of regulation" to "necessity of the product" in justifying regulation, stating that "modern public policy is far from satisfied with regulation limited to the protection of consumers in securing essential types and amounts of service at fair prices. Instead, it extends to the encouragement of abundant use of service...." As to monopolistic conditions of service, Bonbright had this to say: ${ }^{8}$

What favors a monopoly status for a public utility is not the mere fact that, up to a certain point of size, it operates under conditions of decreasing unit cost - an attribute of every business, including a farm or a hand laundry. Nor is it even due to any indefinite extension of the declining-cost portion of a curve relating unit costs of production to scale of output. It is due, rather, to the severely localized and hence restricted markets for utility services - markets limited because of the necessarily close connection between the utility plant on the one hand and the consumers' premises on the other.

This concept of a public utility quite neatly accords to empirical data gained from experience with distribution and transmission networks involving telephones, electricity, water and gas. It can be applied with little distortion to natural gas processing plants. The concept does not, however, fit so well with the experience of enterprises primarily organized to explore for and develop oil and gas properties. Notwithstanding the apparent lack of philosophical justification for regulating them as public utilities per $s e,{ }^{9}$ owners of production and processing facilities have been subjected to the provisions of the Gas Utilities Act and the Public Utilities Board Act. They have become known as "technical owners" because, technically, they fall within the definitions of "owner", "gas utility" and "public utility" in the statutes.

The statutory provisions which have most frequently impinged on a technical owner's operations are those which require Board approval of equity and debt financing and of mergers, mortgages and other dispositions. Although the Board has authority to issue certain exemption orders, technical owners and their legal counsel continue to encounter difficulties in commercial practice.

The purpose of this paper is to identify some of these difficulties. The relevant statutory provisions will be examined both from an historical perspective and from the perspective of jurisdiction and other legal issues. Some suggestions will be offered as to legislative amendments which might remedy the difficulties. On a practical note, some suggestions will be offered as to ameliorative actions which may be taken by a technical owner or its legal counsel.

5. Eli W. Clemens, Economics and Public Utilities (1950) 25.

6. James C. Bonbright, The Public Utility Concept (1961).

7. Id. 7.

8. Id. at $12-13$.

9. It is not intended that general regulation of the oil and gas industry be the subject of comment in this paper. The authority for such regulation lies in a plethora of statutes, both provincial and federal. This paper addresses such legislation only in so far as it appears to have affected the Board's jurisdiction from time to time. 


\section{DIFFICULTIES IN PRACTICE}

The accelerating increase in the number of exemption orders indicates that most lawyers acting on a transaction involving a technical owner consider that the Gas Utilities Act and the Public Utilities Board Act could have a wide application. In all fairness, it must be noted that counsel may be acting out of an abundance of caution when they obtain exemption orders. Their clients' interest is in closing the transaction. They want a proper legal title to pass. In the midst of a share issue, an acquisition of property or a merger, the clients' attention is not likely to be focussed on what is, in that context, a minor particular. Nor is counsel's primary focus likely to be directed to Board approval. Other exigencies prevail. Nevertheless, if there is a possibility that a transaction could be frustrated for lack of Board approval or an exemption order, then the only rational course is to obtain it. Obtaining an order usually does not pose any difficulty, if application is made to the Board sufficiently in advance of the transaction's closing date.

It is useful at this point to review the exemptions practice of the Board since 1974. ${ }^{10}$. The criterion adopted by the Board from the first was whether an owner directly served the public. ${ }^{11}$ If not, then the Board was prepared to declare that certain sections of both the Gas Utilities Act and the Public Utilities Board Act were not to apply to the owner. The sections from which exemption was most frequently granted were those requiring financing and disposition approvals. The standard form of order contained a statement that " . . . the said provisions are not to apply to the Applicant for so long as this order remains unrevoked by the Board."12 After February, 1975, another clause was added to the standard form of order, namely: ${ }^{13}$

This Declaration is subject to the condition that the Applicant comply with the said Undertaking of the Applicant filed with the Board.

The undertaking referred to imposed on an owner the obligation to report to the Board, in summary fashion, the details of every transaction which would otherwise require approval together with a statement deposing to the current nature of the owner's service to the public. The reporting letter was to be given to the Board "prior to the effective date of any transaction". ${ }^{14}$

Until 1978, the Board granted both retroactive orders and current orders. The effective date of retroactive orders could be the date of an owner's incorporation or extra-provincial registration in Alberta or a date convenient to an individual owner. ${ }^{15}$ The practice of granting retroactive orders was discontinued following the 1978 Western Decalta decision. ${ }^{16}$

10. It would appear from the Board's Annual Reports for 1973 and 1974 that the practice of granting exemption orders did not become standard until the latter year. In 1973, the Board reported no exemption orders; in 1974, 49 were reported.

11. Alberta Public Utilities Board Guidelines dated May 17, 1977 \& 1.03.

12. Id. Appendix 4.

13. See, for example, Board Order No. C75078 dated March 27, 1975.

14. And see Board Guidelines, May 17, 1977; Appendix 3.

15. Id. $\$ \S 2.03,2.04$.

16. Western Decalta Petroleum Ltd. et al v. Alberta Public Utilities Board (1978), 9 A.R. 175 (Alta. App. Div.). The Court held that the Board had no power to make retroactive rate increases. 
On July 7, 1980, the Board issued Guidelines to replace the earlier ones dated 1977. Paragraphs 3.01 and 4.01 provided as follows:

The Applicant must establish sufficient grounds to demonstrate why such an Order should be granted. Some of the factors which will be considered are:

(a) Whether the Appplicant directly furnishes or supplies gas to the public of Alberta or any member thereof, whether an individual or a corporaton; and

(b) Whether any member of the public of Alberta is or is likely to be adversely affected by such an Order.

The Board has a statutory duty to generally supervise gas utilities and the owners thereof pursuant to section 21 of The Gas Utilities Act. Orders granted pursuant to section 3(1)(c) of the said Act therefore will be subject to the condition that the Applicant complies with the Undertaking in the form attached....

The standard undertaking was substantially the same as before, except that an owner was now obliged to report to the Board "prior to the closing date of any transaction" rather than prior to its effective date. ${ }^{17}$ The standard form of order was changed only to the extent that it declared a statutory provision inapplicable both to an owner's gas utility and to an owner itself.

On June 16,1981, the Board issued the first of a series of new exemption Guidelines. ${ }^{18}$ Since the statutes had been amended in 1980 , it was now possible for the Board to declare that a person is not, for the purposes of the Act, an owner. ${ }^{19}$ The Guidelines deal only with this type of declaration. They begin by stating that: ${ }^{20}$

The Board considers that the definition of 'public utility' . . and of 'gas utility' . . . may have the effect of applying those acts in circumstances where such serves no useful purpose at this time. The application of the Public Utilities Board Act and the Gas Utilities Act, and the imposition of utility regulation where such serves no useful purpose, impedes, unnecessarily, the conduct of the affairs of some members of the public of Alberta and may thereby adversely affect their rights.

Under the heading "Board Position", the Guidelines indicate that the Board will grant exemptions "in circumstances where the Board is satisfied that no member of the public of Alberta will be adversely affected by" an exemption order. "The criteria which are considered by the Board to be both necessary and sufficient" to so satisfy it, are summarized in paragraph 2.02 of the Guidelines.

Essentially, there are two criteria; one related to the type of utility and the other related to the type of service provided by an owner. As to the first, an owner must demonstrate that it does not own, operate, manage or control a public utility as defined in the Act ${ }^{22}$ or a gas utility. Two types of gas utility are stipulated. One type is "any system... for the production ... furnishing or supplying of gas by retail or wholesale, either directly or indirectly, to or for the public ..." which is used to supply gas directly to the general public. The other type is "any thing that has been declared by the Energy Resources Conservation Board to be a gas utility". The Board's Guidelines then state that::

17. Board Guidelines dated July 7, 1980; Appendix III.

18. The latest Alberta Public Utilities Board Guidelines are dated February 25, 1982. Unless otherwise stated, reference will be made to these Guidelines.

19. The Gas Utilities Amendment Act, S.A. 1980, c. 21; The Public Utilities Board Amendment Act, S.A. 1980, c. 42.

20. Supra n. 18 at $\$ \$ 1.01,1.02$.

21. Id at $\$ 2.01$.

22. Except that reference to an oil pipeline has been changed in the Guidelines to read "has been declared ... to be a common carrier."

23. Supra n. 18 at $\$ 2.03$. 
It is recognized that an understanding of the distinction between the various types of gas utilities which is the subject of paragraph 2.02 is not easily conveyed. For clarity, the words 'any thing for the furnishing or supplying of gas directly to the general public of Alberta that is a gas utility by virtue of section 1/g)/iiv of the Gas Utilities Act" as they are used herein are intended to refer to those facilities used in the provision of conventional gas utility services to the general public, and in respect of which there is generally considered to exist a requirement for regulation in order to properly conserve the public interests. In other words, the ... [italicized] words are intended to 'capture' fully regulated gas utilities of the kind typified by the operations of Northwestern Utilities Limited, Canadian Western Natural Gas Company Limited, ICG Utilities (PlainsWestern) Ltd. to name but three examples. For purposes herein, such are distinguished from other things which are gas utilities by virtue of section $1(\mathrm{~g})$ of the Gas Utilities Act, and which are the subject of subclause (2) of paragraphs $2.02 \mathrm{a}$. and $\mathrm{b}$.

The subject last referred to, the second criterion, is the type of service provided by the owner. An owner must demonstrate either that its public or gas utility does not serve any member of the public or, if it does, that notice has been given to the consumers and "there is no objection or opposition to the application" for an exemption order. ${ }^{24}$ The notice must be served "personally or by ordinary mail" thirty days prior to a hearing "unless there is adduced evidence that there is no objection to the application".25

Those are the "necessary and sufficient" criteria discussed in the text of the Guidelines. It would appear from the appendices that there is one further criterion which the Board applies. The standard forms of affidavit to be filed in support of an application all require that an applicant depose that it "may be or may become an owner" of a gas or a public utility as defined in the statutes. The issue is locus standi. The Board is apparently prepared to issue exemption orders whether or not an applicant has established the jurisdictional facts which would bring it within the purview of the Gas Utilities Act or the Public Utilities Board Act. ${ }^{26}$

The standard form of order is described in the Guidelines under the heading "Conditions". There it is stated that an order, "if not varied or rescinded by the Board, shall remain in full force and effect for so long as" an owner does not "own, operate, manage or control" any of the types of public or gas utility which the owner had referred to in its affidavit. ${ }^{27}$ Furthermore, an order will "require" an owner "to advise the Board in writing forthwith upon the happening of any event whereby" an owner does own, operate, manage or control such a public or gas utility. ${ }^{28}$ Finally, the standard form of order as currently issued contains a paragraph similar to the following: ${ }^{29}$

This order supersedes and replaces any previous Order of the Board made pursuant to section 3(1)

of the Gas Utilities Act in respect of the Applicant and any requirement for compliance with any

undertaking made or given by the Applicant as a condition of any such previous Order is hereby

waived and cancelled.

Against this background and against the legislative background as it existed from time to time ${ }^{30}$ difficulties encountered in practice can be

24. Id. at $\S 2.02(\mathrm{~b})(2)$.

25. Id. at $\$ \$ 4.03,4.04$.

26. Both statutes contain a section that dictates the circumstances in which the Act is to apply. In both cases, a gas or a public utility must exist, and a person must be the owner or must own or operate it before the Acts apply. The sections are discussed more fully under the heading "Jurisdiction", infra.

27. Supra n. 18 at $\$ 3.01$.

28. Id. at $\$ 3.02$.

29. See, for example, Order No. C82245 dated April 1, 1982.

30. Discussed under the heading "Legislative History", infra. 
brought into focus. It is to be remembered that a lawyer acting on a transaction involving a technical owner is required to give his or her opinion that the purchaser, mortgagee, trustee or underwriter has acquired good title to the property in question. The lawyer is accountable for his or her opinion. Opinions may be qualified, but it is more often the case that a client will insist on an unqualified opinion. Therein lies the rub.

Failure to obtain approvals or an exemption order from the Board carries with it a statutory penalty. In the case of a sale, lease, mortgage or other disposition or encumbrance, a merger or consolidation or a sale or transfer of more than $50 \%$ of an Alberta corporation's shares, the transaction is declared by the statutes to be "void and of no effect". ${ }^{31}$ An approval or exemption order would avoid the nullity, but situations can and do arise in which the nature of either the technical owner or the transaction does not permit of either a timely or a valid order. Some examples follow:

\section{A. Nature of Owner}

1. Suppose that companies $\mathrm{A}, \mathrm{B}$ and $\mathrm{C}$ are to amalgamate on Friday afternoon. At least two of them are owners of a gas or a public utility and all necessary exemptions or approvals to amalgamate under the Gas Utilities Act or the Public Utilities Board Act are in place. The newly formed company, Amalco, will, on closing, immediately be an owner and will immediately issue equity shares. Can Amalco get an exemption order before it comes into existence or must it wait until it does come into existence ${ }^{32}$ Does it need an order or can it rely on section $180(\mathrm{f})$ of the Business Corporations Act? ? $^{33}$

2. Given that an extra-provincial corporation owns the shares of an owner of a gas or a public utility and is about to enter into a financing or disposition transaction involving that owner, does it need or can it get the approval or exemption?

3. Assume that an individual has invested in a joint partnership scheme organized for the exploration of oil and gas. A change in tax laws makes it advantageous to reorganize the scheme and the individual wishes to transfer his interest. Does his interest qualify him as an owner?

\section{B. Nature of Transaction}

1. If an owner of a gas or a public utility is about to issue share purchase warrants, is an approval required?

2. Suppose that a person acquires an option to purchase a gas utility. Does the owner of the gas utility require an approval to grant an option to

31. The Gas Utilities Act, R.S.A. 1980, c. G-4, ss. 25(1)(h) and 26; The Public Utilities Board Act, R.S.A. 1980, c. P.37, ss. 91(1)(h) and 92. For a fuller exposition, see the discussion under the heading "Other Legal Issues", infra.

32. Financing and disposition approvals and exemption orders are normally dealt with at "in-office hearings" by a single member of the Board. S. 18 of the Public Utilities Board Act requires that a single member report to the (full) Board which may then adopt the report as the order of the Board. The Board deals with single member reports every Thursday afternoon. Alternatively, a division of the Board may be appointed pursuant to $\mathrm{s}$. 5 of the said Act. A minimum of two Members is required for a division. A decision or action of a division is "the decision or action of the Board and binds all members of the Board". (s. 5(3)).

33. R.S.A. 1980, c. B-15, s. 180(f): "on the date shown in a certificate of amalgamation, ... . a conviction against, or ruling, order, or judgment in favour of or against, an amalgamated corporation may be enforced by or against the amalgamated corporation". 
purchase when that grant is made or only later, when the option is about to be exercised? Presumably, when the option is exercised, the option is extinguished and no approval in respect of an extinguised option would be appropriate. However, other approvals may be necessary depending on the nature of the transaction which follows. If a transfer of shares or assets is involved, do all or just a portion of them pass to the purchaser? What sections of the Acts then apply?

3. Given that a gas or a public utility is being sold and has, in fact, been sold several times in the past to a chain of successors in title, will an approval or exemption covering the current transaction ensure that today's purchaser will get good title to the property?

4. Assume that an owner of a gas or a public utility is about to enter into a trust indenture pursuant to which it will issue unsecured long term debt obligations in series from time to time. The indenture contains a "negative pledge" to the effect that the owner

... will not mortgage, pledge, charge or otherwise encumber or permit any subsidiary to mortgage, pledge, charge or otherwise encumber, any of the assets of the Company or of a subsidiary to secure any indebtedness, unless at the same time it shall secure, in the opinion of Counsel, equally and rateably with such indebtedness all of the debentures then outstanding by the same instrument or by other instrument in form and substance satisfactory to such Counsel.

Can the owner get an approval or exemption for future pledges that the owner has contracted to deliver in certain events?

These are but a few examples of the conundrums which regularly face lawyers acting on transactions involving a technical owner. In addition, there are all the problems arising out of an inadvertent failure to comply with the Acts or a reporting condition in an exemption order. The failure being discovered too late, a lawyer and his client are then faced with the awesome fact that the Acts provide no procedure for curing a fundamental and probably fatal defect.

\section{LEGISLATIVE HISTORY \\ "The Act is by no means logical or accurate"}

Chief Justice Harvey, 1920. ${ }^{34}$

"An Act respecting Public Utilities, to create a Public Utility Commission, and to prescribe its Powers and Duties", known as "The Public Utilities Act", first came into force in Alberta on October 7, 1915. ${ }^{35}$ The Act defined "public utility" to mean and include ${ }^{36}$

every corporation other than municipal corporations (unless such municipal corporation voluntarily comes under this Act in the manner hereinafter provided), and every firm, person or association of persons, the business and operations whereof are subject to the legislative authority of this province, their lessees, trustees, liquidators, or receivers appointed by any court that now or hereafter own, operate, manage or control any system, works, plant or equipment for the conveyance of telegraph or telephone messages or for the conveyance of travellers or goods over a railway, street railway, or tramway, or for the production, transmission, delivery, or furnishing of a water, gas, heat or light power, either directly or indirectly, to or for the public; also, the Alberta government telephones, now managed and operated by the Department of Railways and Telephones;

34. In re The Public Utilities Act, Northern Alberta Natural Gas Development Company Limited v. City of Edmontom [1920] 1 W.W.R. 31, 34 (Alta. App. Div.).

35. S.A. 1915, c. 6 .

36. Id., s. 2(b) as am. by S.A. 1917, c. 3 to read "... furnishing of water, gas, heat, light or power". 


\section{and stated that the Act was to apply ${ }^{37}$}

(a) To all public utilities as hereinbefore defined, which are now or may hereafter be owned or operated by or under the control of the government of the province;

(b) To all such public utilities that shall be owned or operated by or under the control of any company or corporation that is subject to the legislative authority of the province; and

(c) To every person, company or corporation owning or operating any public utility as hereinbefore defined including railway, street railway, or tramway to which the jurisdiction of the province extends, but not including any railway, street railway, tramway or other public utility owned and operated by any municipality which has not passed a by-law under section 4 hereof.

\section{Among other provisions, the Act stipulated that ${ }^{38}$}

\section{no public utility ... shall}

Issue any stocks, stock certificates, bonds or other evidences of indebtedness, payable in more than one year from the date thereof, until it shall have first obtained authority from the board for such proposed issue; it shall be the duty of the board, after hearing to approve of any such proposed issue maturing in more than one year from the date thereof, when satisfied that the same is to be made in accordance with law and the purpose of such issue be approved by said board; (or)

Without the approval of the board, sell, lease, mortgage or otherwise dispose of or encumber its property, franchises, privileges or rights, or any part thereof; or merge or consolidate its property, franchises, privileges or rights, or any part thereof, with that of any other public utility as herein defined; every sale, lease, mortgage, disposition, encumbrance, merger or consolidation made in violation of any of the provisions hereof shall be void and of no effect; nothing herein contained shall be construed in any wise to prevent the sale, lease or other disposition by any public utility as herein defined of any of its property in the ordinary course of its business.

\section{Furthermore, ${ }^{39}$}

No public utility as herein defined, incorporated under the laws of this province, shall sell, nor shall any such public utility make or permit to be made upon its books any transfer of any share or shares of its capital stock to any other public utility as herein defined, unless authorized to do so by the board; nor shall any public utility as herein defined, incorporated under the laws of this province, sell any share or shares of its capital stock or make or permit any transfer thereof to be made upon its books, to any corporation, domestic or foreign, the result of which sale or transfer, in itself or in connection with other previous sales or transfers, shall be to vest in such corporation a majority in interest of the outstanding capital stock of such public utility corporation unless authorized to do so by the board. Every assignment, transfer, contract or agreement for assignment or transfer by or through any person or corporation to any corporation in violation of any of the provisions hereof shall be void and of no effect, and no such transfer shall be made on the books of any public utility corporation. Nothing herein contained shall be construed to prevent the holding of stock heretofore lawfully acquired.

The creation of a Board of Public Utility Commissioners was much heralded in 1915 by the newspapers of the day and by members of the Legislative Assembly. The Edmonton Journal quoted James R. Lowery, an opposition Member, as saying "I heartily endorse the principle of the bill and will welcome its establishment providing men of capability and independence are selected as commissioners." 40 The Government's primary motivation for introducing the bill, Mr. Lowery continued, had been a desire "to shift certain responsibilities" with regard to the telephone system. Apparently it was in urgent need of an unpopular rate increase to regain financial viability. ${ }^{41}$ Later, when G.H.V. Bulyea was appointed as first chairman, the Calgary News Telegram conducted something of an editorial campaign reminding readers of both previous and current imbroglios involving railroads and gas companies. ${ }^{42}$ The perceived problem

37. Id, s. 3.

38. Id, ss. 29(e), (g).

39. Id., s. 30.

40. Edmonton Journah April 16, 1915.

41. Id.

42. Calgary News Telegram, October 28, November 25, and December 30, 1915; January 3 and January $7,1916$. 
in all cases was money: who would be required to pay for what?

In 1916, the Act was amended to require all companies not subject to the legislative authority of the Province and in a franchise or contractual relationship with a municipality to "submit the business and operations thereof to the same control and supervision" of the Board as if the company were constitutionally subject. ${ }^{43}$ Control was maintained by the Board's power over municipalities. All local authorities were required to obtain prior Board approval of franchises and supply contracts. Otherwise, the contract was "absolutely null and void".

For the first few years of its existence, the Board was occupied less with matters arising out of its public utility jurisdiction and more with municipal and securities matters. ${ }^{44}$ The Board's jurisdiction over this latter concern was conferred by the 1916 Sale of Shares Act ${ }^{45}$ which was a statute of general application. It required all persons, whether incorporated or not, to obtain Board certification prior to a sale of shares and other securities. The Board was empowered to issue a certificate if two conditions were satisfied: the person proposing the scheme had to be solvent and he had also to provide a "fair, just and equitable plan for the transaction of business". ${ }^{46}$ In 1929 , the Board's general securities jurisdiction was transferred to a registrar appointed pursuant to the Security Frauds Prevention Act. ${ }^{47}$

When the Statutes of Alberta were revised and consolidated in 1922, the Public Utilities Act emerged reconstituted..$^{48}$ For the first time, a distinction was drawn between the public utility and ownership thereof. The definitions read as follows: ${ }^{49}$

'Public Utility' shall mean any system, works, plant or equipment for the conveyance of telegraph or telephone messages or for the conveyance of travellers or goods over a railway, street railway, or tram way, or for the production, transmission, delivery or furnishing of water, gas, heat, light or power, either directly or indirectly, to or for the public;

'Proprietor of public utility' or 'proprietor' shall mean every corporation other than municipal corporations which have not voluntarily come under this Act in the manner hereinafter provided and every firm, person or association of persons, the business and operations whereof are subject to the legislative authority of this Province and their lessees, trustees, liquidators, or receivers appointed by any court that own, operate, manage or control any public utility.

The application, financing and disposition approval sections were not

43. S.A. 1916, c. 3, s. 23(1).

44. Board Annual Reports, 1917 and 1918.

45. S.A. 1916, c. 8. The booming oil and gas industry prompted enactment of securities legislation. As stated in Gould, The History of Canada's Oil and Gas Industry (1976) 76-77:

Of 57 (oil) companies listed, with millions and millions in shares sold, only 12 wells were being drilled in 1915 ... Due to over-investment in many projects which had little chance of success it was difficult later on for companies with real prospects to attract needed capital ... (The Board, under the) 'Sale of Shares Act' put investment on a more orderly basis and gave some protection to the investor. It was small consolation to those who had lost their life savings....

46. Id., s. 9.

47. S.A. 1929, c. 10.

48. R.S.A. 1922, c. 20. These changes were not made by way of an amending statute. They appear to have resulted from some draftsman's "helpful" housekeeping. A similar change occurred in the 1980 revision of the Public Utilities Board Act. In s. 81(a) for example, the words "mileage and other special rates" were replaced with "travel allowance and other special rates". In the context of public utilities, "mileage" and "travel allowance" are not synonymous.

49. Id., ss. 2(c), (d). 
substantially changed from the 1915 statute except to the extent that the word "proprietor" was inserted where appropriate..$^{50}$ Only one year later, the Act was repealed and rewritten, being entitled "An Act to Prescribe the Duties of the Board of Public Utility Commissioners". ${ }^{51}$ However, the Board's jurisdiction over public utilities and proprietors thereof was not affected $; 2$ the changes affected the Board's jurisdiction over municipal finances and land.

In 1927, the Board's jurisdiction over natural gas was extended by the addition of a section which stipulated that::

The Board shall have jurisdiction over every contract or agreement entered into on or after the first day of May, 1923, between any proprietor of a public utility and any other corporation or person for supplying to the said proprietor, natural gas, or for the transportation, scrubbing, cleansing or otherwise treating natural gas; and thereupon the corporation or person party to any such contract shall for the purposes of this section be deemed to be the proprietor of a public utility so far as relates to the price payable under such contract, and shall so far as last aforesaid be subject to all the provisions of this Act, and upon the application of any person interested, the Board may by order fix the maximum price which may be charged or paid under any such contract, and the price payable under the contract shall be the price fixed by the Board and no other.

In reporting the Legislative debates on the Bill which effected this amendment, the press reflected a lack of Members' concern with the new section. ${ }^{54}$ Comment was reserved solely for an extended right of appeal on a question of law which was proposed by an opposition Member and incorporated into the amending statute. Reference was also made to the Government's repeal of a requirement for municipal concurrence in a change in franchise rates, but nothing, as reported, was said of the Board's new power to control "upstream" activities.

The provisions of the Act regarding what later became known as gas utilities were not further amended until $1941 .{ }^{65}$ In the meantime, Alberta had taken possession of its natural resources in 1930 (albeit constrained by having to carry out contracts previously made by the federal government) $)^{56}$ and Canada was at war. At the first session of the ninth legislature, the Honourable E.C. Manning, Minister of Trade and Industry, spoke in the budget debate of the importance of provincial industry both as part of the war effort and as a continuing post-war effort. ${ }^{57}$ During that same session, several acts were passed having to do with regulation of the oil and gas industry, including one which amended the Public Utilities Act, $1923^{58}$ in the following particulars: it expanded the

50. Id, ss. 3, 37(e), (g), 38.

51. S.A. 1923 , c. 53.

52. The relevant sections were now numbered $2(\mathrm{~g})$ and $(\mathrm{h}), 51,68(\mathrm{e})$ and $(\mathrm{g}), 69$ and 70 .

53. The Public Utilities Act, 1923, Amendments Act, 1927, S.A. 1927, c. 39.

54. Edmonton Journal, March 26, 1927 as an example.

55. Major amendments affecting public utilities were as follows: S.A. 1928, c. 45 added a section regarding the supply of electricity, which was not to be provided by a franchise or privilege, "exclusive as against His Majesty in right of the Province" and which was not to be approved unless the Board was satisfied that the scheme "is reasonable and sufficient" and "to the general benefit of the area directly or indirectly affected thereby". S.A. 1929, c. 30 added the power to direct "connection, reconnection or the maintenance of the existing connection" of telephone systems. S.A. 1933, c. 18 and S.A. 1934, c. 65 added the production, distribution and sale of milk to the definition of "public utility".

56. The Alberta Natural Resources Act, S.A. 1930, c. 21 and B.N.A.Act, 1930 (20-21 Geo.V, c. 26, U.K.).

57. As reported in the Edmonton Bulletin, March 14, 1941.

58. The Public Utilities Act, 1923, Amendment Act, 1941, S.A. 1941, c. 55. Other statutes enacted include: The Oil and Gas Fields Public Service Utilities Act, S.A. 1941, c. 68; The Unit Operation of Mineral Resources Act, S.A. 1941, c. 69. 


\section{definition of "public utility" to include}

any system, works, plant, equipment or service for the production, gathering, conveying, transmission, transporting, delivery, furnishing or supplying by wholesale or by retail either directly or indirectly to or for the public or any member of the public of gas including gas in its natural state as and when produced from the earth either alone or in association with other petroleum products and including gas both before and after it has been subjected to any treatment or process by absorption or otherwise for the extraction therefrom of natural gasoline and both before and after it has been purified, scrubbed or otherwise treated for the extraction or removal therefrom of sulphuretted hydrogen or other deleterious substance, and whether the gas is delivered, furnished or supplied to the public or any member of the public either before or after it has been so treated, processed, purified or scrubbed; and

any system, well, works, plant, equipment or service for the production of gas including gas in its natural state as and when produced from the earth either alone or in association with other petroleum products whenever such gas is not being subjected to any treatment or process by absorption or otherwise for the extraction therefrom of natural gasoline

and it added to the Board's powers by adding a new paragraph to section 63, namely:

to require every proprietor of a public utility as defined by section 2, paragraph (h), to supply and deliver to such persons and for such purposes and at such rates, prices and charges and upon such terms and conditions as the Board shall from time to time direct, fix or impose, gas including gas in its natural state as and when produced from the earth either alone or in association with other petroleum products and including gas both before and after it has been subjected to any treatment or process by absorption or otherwise for the extraction therefrom of natural gasoline and both before and after it has been purified, scrubbed or otherwise treated for the extraction or removal therefrom of sulphuretted hydrogen or other deleterious substance.

The purpose of this amendment, as reported in the press, was to allow for enforcement of a scheme whereby wastage of gas in the Turner Valley field would be controlled, in part by returning it to the field. This had the effect of repressuring the field to permit more crude oil production. ${ }^{59}$ The amendments were carried forward unaltered to the 1942 Revised Statutes. ${ }^{80}$.

By 1944, the Government apparently saw a need to intervene on behalf of Turner Valley gas producers who had no means to process or transport their gas to market. ${ }^{61}$ The consequence was the Natural Gas Utilities Act which, inter alia, repealed the 1927 amendment to the Public Utilities Act. ${ }^{62}$ The New Act constituted a Natural Gas Utilities Board comprised of two members, the chairman of each of the Board of Public Utility Commissioners and the Petroleum and Natural Gas Conservation Board. ${ }^{63}$ The new Board in many respects paralleled the Board of Public Utility Commissioners. There were, however, interesting differences. "Proprietor of a public utliity" was defined without reference to the legislative authority of the Province ${ }^{64}$ and a new definition of "owner" was added: $:^{65}$

'Owner' unless the context otherwise requires, means and includes in addition to its ordinary meaning the person who is operating any oil well or well producing or capable of producing natural gas or who is in charge of the management of such well or who is entitled to dispose of any production of any natural gas from such well or who would be so entitled in the absence of any contract governing the disposition of such production or the owner in fee simple or the lessee or the sublessee or the owner of any right to participate in the said production.

59. Edmonton Bulletin, April 5, 1941.

60. The Public Utilities Act, R.S.A. 1942, c. 28. The relevant sections were now numbered $2(\mathrm{~g})$ and $(\mathrm{h}), 52,66(\mathrm{c}), 71(\mathrm{e})$ and $(\mathrm{g}), 72$ and 73.

61. Edmonton Bulletin, February 18 and March $3,1944$.

62. S.A. 1944, c. 4 and The Public Utilities Act, 1923, Amendment Act, 1927, S.A. 1927, c. 39.

63. S.A. 1944, c. 4, s. 3.

64. Id, s. 2(j).

65. Id., s. 2(f). 
"Public utility" was restricted to "any pipeline", "any scrubbing plant" and "any well, system, works, plant, equipment or service for the production of or capable of producing natural gas" ${ }^{66}$ Once again, it was provided that no proprietor of a public utility shall issue shares or instruments of debt, sell, lease, mortgage or merge or transfer more than $50 \%$ of an Alberta corporation's stock, without Board approval. ${ }^{67}$ These provisions were identical to those in the Public Utilities Act of 1942.

For the first time, however, a form of exemption power was given in connection with public utilities. The Natural Gas Utilities Board had the power $^{68}$

Whenever in the Board's opinion it is necessary or advisable so to do ... to suspend all or any of the provisions of this Part in so far as such provisions may apply to any public utility as defined by this Act.

The Part there referred to was Part II of the Act. It conferred on the new Board and on proprietors of public utilities the same sorts of powers and obligations created by the Public Utilities Act.

Part III of the Natural Gas Utilities Act, however, was new. It prohibited any person from entering into exclusive contracts for sale, supply or transportation of gas to market. ${ }^{69}$ Such contracts were declared null and void and contracts "in any way relating to the transportation, processing, purifying, selling, purchasing, storing and/or otherwise dealing with natural gas" were subject to Board approval. Exempted were franchises having to do with intra-municipal gas distribution but not such franchises as they applied "outside the confines of such municipality". Moreover, the Board had authority to require owners, operators and proprietors to construct pipelines, gather gas, process it, purchase it, return it to underground formations and to sell it, all as stipulated by the Board..$^{70}$ The Board was also required to set the "just and reasonable price or prices" for gas at all points along the chain from well-head to processing and storage. ${ }^{71}$ Finally, proprietors of "any pipeline engaged in gathering, transporting, handling or delivering natural gas" were declared to be common carriers; ${ }^{72}$ such proprietors in "any oil field, gas field or oil-gas field" were to be common purchasers; ${ }^{73}$ and owners and operators of a scrubbing plant were, effectively, to be common processors. ${ }^{74}$

The Natural Gas Utilities Board continued in business until its statutory authority was repealed in $1949 .{ }^{75}$ The Leduc field had been discovered in 1947 and the Redwater field in $1948 .{ }^{78}$ In response, ${ }^{77}$ the Alberta Department of Land and Mines was split into two Departments

66. Id, s. 2(k). Definitions of "absorption plant", "natural gas", "personal property", "pipe line", "plant" and "scrubbing plant" were provided in ss. 2(a), (e), (g), (h), (i) and (i).

67. Id., ss. 52(e). (g), 53, 54 .

68. Id, s. 47(2).

69. Id. s. 67.

70. Id. s. 71 .

71. Id., s. 72.

72. Id., s. 74 .

73. Id., s. 75 .

74. Id, s. 76.

75. An Act to repeal The Natural Gas Utilities Act, S.A. 1949 (2nd Session), c. 4.

76. Supra n. 45 at 99 and 145.

77. Edmonton Bulletin February 19, 1948. 
in 1948, one of which became known as the Department of Mines. ${ }^{78}$ The Dinning Commission had reported its estimates of natural gas reserves and provincial consumption and stated its opinion on two other issues: priority of supply should be given first to Albertans, secondly to other Canadians; and a grid system linking all gas fields was a preferred method of distributing natural gas. ${ }^{79}$ Westcoast Transmission Company had submitted a private bill for permission to export gas from the Province. ${ }^{80}$ "An act to determine all claims from the Atlantic No. 3 oil well disaster in the Colman-Leduc sector" had been given first reading in March, 1949. ${ }^{81}$ The Government took action in the summer of that year. On July 4, a special four day session of the Legislature was convened to consider legislation which would, as reported by Andrew Snaddon, "give the cabinet complete control of the natural gas and oil resources of the province". ${ }^{82}$

In effect, the legislation ${ }^{83}$ divided jurisdiction over natural gas between the Board of Public Utility Commissioners and the Petroleum and Natural Gas Conservation Board. The latter was given authority, with the approval of the Lieutenant Governor in Council, to grant removal permits for gas which was considered surplus to Albertans' needs and, in so doing, to prescribe production and supply conditions. ${ }^{84}$ It was similarly given jurisdiction to control production, processing and storage of oil and gas and the use of gas for other than light or fuel. ${ }^{85}$ Common carrier and common purchaser declarations were to be made by this Board. ${ }^{86}$ The Board of Public Utility Commissioners, on the other hand, was given jurisdiction to fix the field prices of gas at any point in the chain from wellhead to storage $e^{87}$ and the rates, tolls and charges of oil or gas common carriers. ${ }^{88}$ It was at this point in the history of the Board that "public utility" came to be defined as ${ }^{89}$

(i) any system, works, plant, equipment or service for the conveyance of telegraph or telephone messages;

(ii) any system, works, plant, equipment or service for the conveyance of travellers or goods over a railway, street railway or tramway;

(iii) any system, works, plant, equipment or service for the production, transmission, delivery or furnishing of water, heat, light or power, either directly or indirectly, to or for the public;

(iv) any gas pipe line;

78. The Department of Mines Act, S.A. 1948, c. 3; in force April 1, 1949.

79. Alberta Commission on Natural Gas. Report March 8, 1949.

80. As reported in the Edmonton Bulletin, March 16, 1949.

81. Edmonton Journah March 8, 1949; S.A. 1949, c. 17.

82. Calgary Herald, July 4, 1949.

83. There were six gas related Acts passed at the second session of the eleventh legislative assembly; The Gas Resources Preservation Act, S.A. 1949 (2nd session), c. 2; An Act to repeal The Natural Gas Utilities Act, S.A.1949 (2nd session), c. 4; An Act to Amend The Oil and Gas Resources Conservation Act, S.A. 1949 (2nd session), c. 5; An Act to amend The Pipe Line Act, S.A. 1949 (2nd session), c. 6; An Act to repeal The Pipe Line Regulation Act, S.A. 1949 (2nd session), c. 7; An Act to A mend the Public Utilities Act, S.A.1949 (2nd session), c. 8.

84. The Gas Resources Preservation Act, S.A. 1949 (2nd session), c. 2, ss. 7, 8.

85. An Act to amend The Oil and Gas Resources Conservation Act, S.A. 1949 (2nd session), c. 5, ss. 16, 16d.

86. Id., ss. $16 \mathrm{~b}, 16 \mathrm{c}$.

87. An Act to amend The Public Utilities Act, S.A. 1949 (2nd session), c. 8, ss. 70a, 70b, 70c, 70d.

88. Id, s. 70e.

89. Id, s. 2(m). "A bsorption plant" was added by S.A. 1974, c. 44. 
(v) any oil pipe line declared by The Petroleum and Natural Gas Conservation Board to be a common carrier;

(vi) any system, works, plant, equipment or service for the production, gathering, conveying, transmission, transporting, delivery, furnishing or supplying of gas by retail or wholesale, either directly or indirectly, to or for the public or any member of the public;

(vii) any scrubbing plant;

(viii) any system, well, works, plant, equipment or service for the production of gas or capable of producing gas declared by The Petroleum and Natural Gas Conservation Board to be a public utility; [and]

(ix) any plant, premises, equipment, service or organization for the production, processing, handling, bottling, distribution, supply, delivery, keeping for sale or the sale of milk, including products thereof, in a liquid form;

Two other amendments to the Public Utilities Act were consequent upon a restructuring of the regulatory scheme. First, a subsection was added to section 52, such that supply of liquefied petroleum gas by tank car, tank wagon, cylinder or vessel was declared not to be a public utility. ${ }^{90}$ Second, the 1941 amendment which had authorized the Board to require delivery of gas at any stage in its production was now simplified to read "to supply and deliver gas".91

In general, editorial response to the 1949 regulatory changes was favourable. ${ }^{92}$ The Winnipeg Free Press summarized the situation in these words: ${ }^{93}$

The question of the export of natural gas which, in principle, is the same as the export of oil although the question does not arise in the latter case, is of importance not only to residents of that province but to the whole of western Canada. If export is permitted, then great conveying pipe lines will be built across the prairies and to the Pacific Coast and some millions of persons in those areas as well as many industries will be given the opportunity to use a cheap, clean fuel. And there will be adverse effects on the coal mining and distributing business. The Alberta Legislature, and generally the people of Alberta,... see it as a powerful inducement for the development of industries there, a source of power which will contribute heavily to the extraction and processing of the other resources of one of the world's potentially richest areas. ...

Up to now the known gas fields have been found almost wholly as a result of the exploration for oil. Companies drill an oil well. With the oil they get gas and as the oil is extracted a certain amount of gas escapes, although strict conservation regulations are now in effect. If the gas is not used as it comes, it will be wasted and whatever value to Alberta and to western consumers there is in gas will be lost.

At the present time Alberta residents in many small towns and in rural areas do not get gas because it would be too expensive to build pipe lines through sparsely settled areas. But if gas is exported then the province will be covered by a grid of gas pipes to assemble the gas from all the oil fields and oil wells and bring it to central mains. That will provide the province with pipe lines through or adjacent to most of the small towns and make use of gas by them and by rural areas an economic project. Again, the assurance of a market for natural gas would be a great aid to the exploration for oil. A well sunk for oil and finding gas would not be a wasted effort. It would reduce the hazard and cost of exploration and therefore give the small companies an improved chance of making good. Finally, the distribution of gas widely in Alberta itself as a result of the export grid would be a powerful influence towards industrial development on a widely dispersed scale. Every small community could have power to offer.

In 1951, it was announced that by-products of natural gas would be ex-

90. Id., s. 52(3).

91. Id, s. 66(e).

92. Calgary Albertan, July 4 and 7, 1949. Calgary Herald, July 7, 1949.

Edmonton Bulletin July 5 and $7,1949$.

Edmonton Journah, July 7, 1949.

Lethbridge Herald, July 6 and $11,1949$.

Regina Leader-Post, July 9 and 11, 1949.

Winnipeg Free Press, July 8, 1949.

93. July 6, 1949, by W. R. Clarke. Also printed in the Regina Leader-Post, July 11, 1949. 
tracted before the gas was exported.94 In that same year the Public Utilities Act was amended to allow the Board to approve contracts made by an owner or operator of a scrubbing plant for the sale or disposition of natural gas components. ${ }^{95}$ The following year, Westcoast Transmission Company received a permit to remove gas from the Peace River area. ${ }^{96}$ The Board was given more explicit powers in fixing producer prices in the same year. ${ }^{97}$ In 1953, the Board was authorized, with the approval of the Lieutenant Governor in Council, to fix producer prices on an area-wide basis. ${ }^{98}$

It was during the next two years that the first exemption provisions were introduced into the Public Utilities Act. A statutory exemption from financing and disposition approval requirements was enacted in 1953. Added to section 71 , the new subsection read:99

Notwithstanding subsecton (1), the approval, authority, permission or consent of the Board is not required in or with respect to

(a) the issue of any shares of its capital stock by a proprietor under the exercise of any optional right of conversion attaching to any shares, stocks, bonds, debentures, debenture stock or other evidence of indebtedness, the issue of which has previously been approved by the Board, or

(b) a right of entry, sale, disposition or other proceedings for the enforcement of a mortgage or charge created by trust deed or other instrument or security, in the enforcement of, or pursuant to, the security thereby constituted or in the exercise of the rights or remedies thereby granted or otherwise available at law, if such trust deed or other instrument or security was approved or authorized by the Board.

Two years later, following creation of the Alberta Gas Trunk Line Company Limited ${ }^{100}$ and anticipating the TransCanada Pipelines Company Limited, ${ }^{101}$ the Board's declaratory powers were introduced: ${ }^{102}$

(1) The Board may, upon the application of any person having an interest and subject to such terms and conditions as it may require, declare any of the items referred to in subclauses (iv), (vi) or (vii) of clause $(\mathrm{m})$ of section 2 not to be a public utility.

(2) The Board, upon its own initiative or upon the application of a person having an interest, may, after notice and hearing, vary or rescind in whole or in part, any order of the Board made pursuant to subsection (1).

The declaratory power was limited; sections $2(\mathrm{~m})(\mathrm{iv})$, (vi) and (vii) refer only to the definition of "public utility" as meaning "any gas pipe line", "any system ... for the production ... of gas ..." and "any scrubbing plant". At the same time, the Board's powers were further limited in that it was precluded from changing any contract related to gas approved for removal from the Province. The amendments were carried forward

94. Edmonton Journah March 6, 1951 reporting a statement made in the Legislature by the Hon. N. E. Tanner, Minister of Mines and Minerals.

95. An Act to amend The Public Utilities Act, S.A. 1951, c. 71.

96. Calgary Herald; April 10,1952.

97. An Act to amend The Public Utilities Act, S.A. 1952, c. 73.

98. An Act to amend The Public Utilities Act, S.A. 1953, c. 98.

99. Id, s. 4.

100. The Alberta Gas Trunk Line Company Act, S.A. 1954, c. 37. The Act stated, in s. 16, "... except where inconsistent with this Act, the provisions of ... The Public Utilities Act ... are applicable to the company." By the same section, the Lieutenant Governor in Council could suspend application of the Public Utilities Act or any part of it for an indefinite or fixed period. It was not until later, by An Act to amend The Alberta Gas Trunk Line Company Act, S.A. 1970, c. 5, that the company was statutorily exempted from the Gas Utilities Act.

101. Edmonton Journah March 6, 1954.

102. The Statute Law Amendment Act, 1955, S.A. 1955, c. 38, s. 31(b). 
unchanged into the 1955 Revised Statutes. ${ }^{103}$

Between the years 1955 and 1960, there was considerable public debate on the question of consumer gas rates. Concern was expressed that gas exports, now a reality, would necessarily cause a domestic price increase. ${ }^{104}$ The Government's response was to strengthen the Board's powers and to increase its role in setting prices. It was no longer to be constrained from interfering with gas export contracts; it could fix prices at a field gathering point and at the point of delivery to a community or consumer in the Province; it was to approve all consumer rates affected by escalation or "favoured-nation" clauses; and it was required to review, every three years, the affairs of a proprietor for which it had previously fixed rates, tolls or charges. ${ }^{105}$ During this same period, the definition of "public utility" as it relates to gas supply was extended to include any member of the public "whether an individual or a corporation". ${ }^{108}$ Furthermore, the Board's declaratory powers were extended such that it might also ${ }^{107}$

declare that a provision of any section of this Act is not to apply in respect of any public utility referred to in subclause (iv), (vi) or (vii) of clause (m) of section 2 or to a proprietor thereof, and for so long as any such declaration remains unrevoked by the Board, the provision therein mentioned has no application in respect of the public utility so designated therein, or to the proprietor thereof.

Presumed conflict between export and domestic gas prices was also the apparent motivation for two gas distribution companies ${ }^{108}$ to divest themselves of shares in a gas exporting company ${ }^{109}$ in $1960 .{ }^{110}$ However, speaking in the Legislature some four days later, Premier E.C. Manning indicated that consumer gas prices were not as directly related to export prices as "propaganda emanating from some quarters" would have it. "And, in any event," he continued, "increased transmission efficiency and a requirement that domestic supplies be priced as if they came from the nearest gas field greatly reduced consumer prices." Wi1 With a month, two new bills were introduced: the Public Utilities Board Act and the Gas Utilities Act. ${ }^{12}$

The ostensible reason for gathering gas utility legislation into one statute was stated to be to "enable those primarily interested in gas regulations to more easily locate statutes affecting the gas industry."113 Although the Acts were primarily consolidations, they did contain some

103. The Public Utilities Act, R.S.A. 1955, c. 267. The relevant sections were now numbered $2(1)$ and $(m), 22,53,79(1)(e)$ and $(g), 79(2), 80$ and 81 .

104. Edmonton Journal; April 4, 1959.

105. An Act to amend The Public Utilities Act, S.A. 1959, c. 73, ss. 13, 11, 6, 9, 10.

106. An Act to amend The Public Utilities Act, S.A. 1957, c. 75.

107. Supra n. 105, s. 5.

108. Canadian Western Natural Gas Company and Northwestern Utilities Limited.

109. Alberta and Southern Gas Co. Ltd.

110. The shares were traded to the distributors' mutual parent, International Utilities Limited of New York: as reported in the Calgary Herald, February 19, 1960. There seems to have been some Government encouragement to effect the divestiture: Calgary Herald, February 25, 1959.

111. As reported in the Calgary Herald, February 23,1960 under banner headlines "Manning Stands Firm on Gas Jurisdiction".

112. S.A. 1960, c. 85 and c. 37 respectively. The move to rewrite public utility legislation had been predicted by Premier Manning, as reported in the Calgary Herald, February 25, 1959. The Public Utilities Board Act was introduced on March 19, 1960; the Gas Utilities Act on March 26, 1960.

113. Calgary Herald, March 19, 1960. 
revisions. In the Public Utilities Board Act, the word "owner" was substituted for "proprietor"; otherwise the definition was left unaltered. ${ }^{14}$ The words "may be" were inserted in the definition of a "public utility" as "any oil pipe line the proprietor of which may be declared ... to be a common carrier"."15 The application section was reworded but left substantially the same. ${ }^{116}$ The financing and disposition approval sections were unchanged, but the statutory exemption was extended to "the declaration or issuance of a stock dividend by an owner of a public utility." 117 The section regarding transfer of more than $50 \%$ of the shares of an Alberta corporation was rewritten but not substantively affected. ${ }^{118}$ The one conspicuous change was the absence, in the Public Utilities Board Act, of any power to declare exemptions.

The Gas Utilities Act, however, did include the exempting power. It still referred to a gas pipe line, a system for supply of gas and a scrubbing plant but it now allowed the Board to declare that a provision of either the Gas Utilities Act or the Public Utilities Board Act was not to apply to such a gas utility or to an owner thereof. ${ }^{119}$ A new term, "gas utility", was introduced and defined in substantially the same terms as had been a "public utility" except that the words "may be" were inserted in clause (iv): $:^{120}$

'gas utility' means

(i) any gas pipe line,

(ii) any system, works, plant, pipes, equipment or service for the production, gathering, conveying, transmission, transporting, delivery, furnishing or supplying of gas by retail or wholesale, either directly or indirectly, to or for the public or any member of the public whether an individual or a corporation, other than the transportation, delivery, furnishing or supplying by retail or wholesale, either directly or indirectly, of liquefied petroleum gas by means of tank car, tank wagon, cylinder or vessel,

(iii) any scrubbing plant, and

(iv) any system, well, works, plant, equipment or service for the production of gas or capable of producing gas which may be declared by the Oil and Gas Conservation Board to be a gas utility. The term "owner" was substituted for "proprietor"; ${ }^{121}$ the application section exactly paralleled the Public Utilities Board Act, referring to "gas" rather than to "public utilities"; ;22 jurisdiction over field prices of gas was incorporated as Part 1 of the new Act; the financing and disposition sections paralleled the Public Utilities Board Act, complete with an extension to exempt stock dividends from approval; ${ }^{123}$ and the $50 \%$ share transfer section was also the same, except that no transfer was to be made to an owner of either a gas utility or a public utility. ${ }^{124}$

At the time the Gas Utilities Act was introduced, the press was attentive to the question of Alberta's jurisdiction over its natural gas resources. As the Edmonton Journal reported: ${ }^{125}$

114. S.A. 1960 , c. 85 , s. 2(i).

115. Id., s. $2(\mathrm{j})$.

116. Id., s. 70.

117. Id, ss. 87(1)(e), (g), 87(2).

118. Id. s. 88.

119. S.A. 1960 , c. 37, s. 3.

120. Id. s. 2(f).

121. Id, s. 2(i).

122. Id., s. 4.

123. Id, ss. 24(1)(e), (g), 24(2).

124. Id., s. 25.

125. March 26, 1960. The headline read "Bill Will Simplify Gas Utility Laws". 
The bill enunciates clearly Alberta's claim to control over natural gas while it is within the province. Provincial control was questioned recently at national energy board hearings on gas export. Both Edmonton and Calgary raised this point, asking if control of well-head prices for export gas might become a federal matter because the gas is a commodity in interprovincial trade.

At the time Premier Manning said Alberta will fight to uphold its claim that the province has complete jurisdiction over the gas until it crosses provincial boundaries.

The bill says that notwithstanding the terms of any contract, the board of public utility commissioners may fix prices at any point from the well-head to the sale of gas to a utility company, to the ultimate delivery ... to the consumer.

Whether a separate Gas Utilities Act was indeed intended to be a provincial assertion of its jurisdiction is not apparent on the face of it although, certainly, the era of federal encroachment had begun. ${ }^{128}$

In 1962, the Gas Utilities Act was amended by adding provisions which constituted a Gas Utilities Board comprised of three members: the chairman of each of the Public Utilities Board and the Oil and Gas Conservation Board, and a member appointed by the Lieutenant Governor in Council. ${ }^{127}$ The purpose of the new Board was to consider matters over which either of the older Boards had partial or complete jurisdiction, if in their opinion the matters ${ }^{128}$

(a) may affect directly or indirectly the present or future supply of gas for domestic, commercial or industrial purposes within the Province, or the price or conditions under which such gas is supplied, or

(b) having regard to the availability of any other source or supply of gas, to the requirements of users of gas in any part of the Province and to any other circumstances, may affect a public interest.

The 1970 Revised Statutes made no significant changes to either the Gas Utilities Act or the Public Utilities Board Act. ${ }^{129}$ However, a 1970 amendment incorporated into the Revised Statutes had served to clarify the Board's jurisdiction with respect to field prices. ${ }^{130}$ It was thereby made clear that a price was to be fixed only for "gas to be used, consumed, stored or retained within Alberta".

Propane supply within Alberta had become an issue by 1973 . Once again tension between export prices and domestic prices caused a public furore. Because about $85 \%$ of the Alberta production was exported and because of increased international demand for propane, there occurred within Alberta "an upward pressure on propane prices at the producer level and consequently at all levels ...."131 There existed, however, a regulatory gap and so, in the Gas Utilities Act, the definition of "gas utility" was revised in 1973 to include propanes and butanes but not other liquefied petroleum gas transported by tank car and similar means. ${ }^{132}$ The

126. See, for example, the report in the Edmonton Journah, March 30, 1962. Under headlines stating "Provincial Sovereignty In Jeopardy" an article by Doug Sagi opened "Provincial sovereignty will be in danger until the federal government changes its financial policies, Premier E. C. Manning said in the Legislature".

127. An Act to amend The Gas Utilities Act, S.A. 1962, c. 28. These provisions were subsequently amended by S.A. 1964, c. 31; S.A. 1965, c. 34; S.A.1970, c. 50;S.A.1971, c. 30; S.A. 1975, c. 30; S.A. 1978, c. 50.

128. An Act to amend The Gas Utilities Act, S.A. 1962, c. 28, s. 49(b)(i).

129. R.S.A. 1970 , c. 158 and c. 302 respectively. The relevant sections were now numbered as follows: in the Gas Utilities Act, 2(f) and (i), 3, 4, 24(1)(e) and (g), 24(2), and 25; and in the Public Utilities Board Act, 2(i) and (j), 70, 87(1)(e) and (g), 87(2) and 88.

130. An Act to amend The Gas Utilities Act, S.A. 1970, c. 50.

131. "Board Preliminary Report Respecting Propane Used, Consumed, Stored or Retained in Alberta" dated December 3, 1973. See Appendix 6, Part 9.

132. S.A. 1973, c. 91; in force March 6, 1974. 
same amendment altered the wording of section 6 , allowing inter alia for immediate implementation of prices ordered to be fixed by the Lieutenant Govenor in Council. A new section was added referring specifically to propanes and butanes and limiting price increases until the Board had fixed or approved them. Events leading up to these amendments and events immediately following were summarized by the Board as follows: ${ }^{134}$

In the early fall of $\mathbf{1 9 7 3}$ propane was being used for space heating by tens of thousands of Alberta households. Prior to that time the average consumer price of propane for this use had been reasonably stable at approximately $14 \mathrm{C}$ per gallon.

A very rapid escalation in the price of propane began to take place in the latter part of 1973, and the Premier, the Hon. Peter Lougheed, and the Minister of Telephones and Utilities, The Hon. Roy Farran, responded to this by holding urgent discussions with producers and distributors. As a result, there was a voluntary rollback of prices at both the producer and distributor level which resulted, generally, in the maximum consumer price for propane being established at 21c per gallon, with allowance in the more remote parts of the Province for haulage charges ...

It became apparent that market pressures were jeopardizing the industry agreement, and consequently The Gas Utilities Amendment Act was proclaimed on March 6,1974 which put the entire problem in the hands of the Public Utilities Board.

The Public Utilities Board immediately advised the producers and distributors to file their existing prices with the Board. This had the effect of freezing those prices at the levels which had been established by agreement. The Board instituted a monitoring procedure to ensure that no further escalation took place. Since that time there has been no change in the price and it has remained stationary. It cannot be increased without the approval of the Public Utilities Board, and no such approval has been issued to this date. ... ${ }^{133}$

However, during this period of relatively stable prices the same market pressures continued which created the problem in the first place and which, if allowed free rein, would have pushed the consumer prices up above the 21C level... The Board decided that it would move without a specific application from any distributor or producer in the Province for a price increase, and that it would select a major propane distributor to bring the matter into focus. It has, therefore, decided to inquire into the justness and reasonableness of the prices charged by Canadian Propane Ltd., a company which supplied more than $50 \%$ of the propane used for space heating in the Province.

In addition to pricing and supply, several other factors have emerged which will be explored at the hearing. There is the question of the use of propane as a farm fuel, and this involves not only tractor usage but usage in irrigation schemes. The question of propane safety, both in storage in bulk, in storage at users' premises, and in transit will be covered.

In due course, the Board issued its order, setting up an allocation plan whereby the principal suppliers of propane were required to supply Alberta distributors at a price of not more than $10.5 \mathrm{C}$ per gallon. ${ }^{135}$ The following year, it increased the price to $14 \mathrm{C}$ per gallon. ${ }^{136}$ Dome Petroleum Limited appealed the Board's order; the Supreme Court of Canada upheld it. ${ }^{137} \mathrm{By} 1977$, after several years of regulation and during changed market conditions, the Board had concluded that a sufficiently competitive market existed to control prices and quality of propane service. Accordingly, it ceased to price-regulate the propane industry. ${ }^{138}$

At the height of the propane controversy, "a case of urgency respecting the supply and price of butanes for use in highway construction and maintenance in Alberta" had also arisen. ${ }^{139}$ The Board had immediately

133. June 6, 1974.

134. Statement issued by the Board "with a view to bringing up to date the situation for the information of those Alberta citizens who have shown concern".

135. Board Order No. 30874 dated October 24, 1974.

136. Board Decision No. C75141 and Order No. C75142 both dated May 2, 1975.

137. [1977] 2 S.C.R. 822.

138. Board Order No. C77147 effective March 31, 1978 (as to producers) and No. C77148 dated June 30, 1977 (as to distributors). The Board continues to monitor propane prices: Board Annual Report, 1981 at 78 and 79.

139. As recited in the style of cause of Board Order No. 30763 dated May 31, 1974. 
responded by ordering a sufficient supply to be delivered at $7.5 \mathrm{C}$ per gallon. ${ }^{140}$ Apparently this quick and definitive response was sufficient to resolve questions of butane supply.

Propane was one issue in 1973; that year, there were other issues of paramount importance in the history of Alberta energy legislaton. ${ }^{141}$ It was the year of the "Energy Session" during which the Alberta Petroleum Marketing Commission was constituted. Subsequently, a new mechanism for natural gas pricing was instituted by the Natural Gas Pricing Agreement Act which came into force on November $1,1975 .{ }^{142}$ Section 11 of that Act effectively limited the Board's jurisdiction to fix gas prices. ${ }^{143}$ Even more effective was an amendment to the Gas Utilities Act enacted on May 19, 1976 and proclaimed on May 27,1976. ${ }^{144}$ By this amendment, the Board was precluded from proceeding with any application to fix prices or rates, tolls or charges unless the Board was authorized to do so either by the Lieutenant Governor in Council or because the application fell within a class exempted from the prohibition by regulation. Regulations were subsequently passed which exempted cases under section 27(a) involving municipally franchised owners of a gas utility, all cases under section $27(\mathrm{~b})$, (c) and (d), and cases under section $27(\mathrm{e})$ in which the Board is empowered to proceed on its own initiative. ${ }^{145}$

The bill to amend the Gas Utilities Act had been given second reading on May 17, 1976. ${ }^{146}$ In debate, the purpose of the bill was stated to be twofold: ". . . consideration of altering private contracts" was to be subject to cabinet authorization; ${ }^{147}$ and the "present status" was to be held "intact [so as to] permit time for a fuller review of natural gas pricing within Alberta". ${ }^{148}$ The Minister further commented that:149

In so saying with respect to clarification of that purpose and principle, Mr. Speaker, it is to be noted ... that the notion of deciding prices between the producer and the purchaser as distinct from a rate of return determination by the Public Utilities Board is not consistent with the basic notion and intent of the Gas Utilities Act .... it is not the government's intention that The Gas Utilities Act be used in this way which is not consistent with utility basic concept. But it is the government's intention that The Gas Utilities Act be used for the normal or ordinary utility rate determinations.

At the time this debate was continuing, the Board had before it an application by several producers to increase their contractual gas prices ${ }^{150} \mathrm{Con}$ :

140. Id., as am. by Order No. 30785 dated on June 24, 1974. The fact of emergency was established on written advice from the Minister of Telephones and Utilities and from the Deputy Minister of Highways and Transport. The said Minister had, inter alia, asked the Board "to use whatever powers may be at [its] disposal to ensure butane supplies for these vital government programs."

141. For a review of historical developments, see McDill, "Natural Gas Pricing in Canada". (1979) 17 Alta. L. Rev. 120.

142. S.A. 1975 , c. 38 .

143. For a discussion of how and to what extent the.Board's jurisdiction was affected, see Edie, "Natural Gas Pricing in Alberta", (1976) 14 Alta L. Rev. 455 at 468-469.

144. S.A. 1976, c. 21. Edie comments on this amendment at $469, I d$.

145. Alta. Reg. 127/76. This has been repealed and replaced by Alta. Reg. 195/82. The new regulations refer, inter alia, to municipally franchised owners, to municipal owners, to owners supplying gas to individual taps (as defined in the Rural Gas Act) and to owners supplying gas to any of the owners mentioned in the first three categories.

146. Alberta Hansard, 1976 at 1376-1379.

147. Id. at 1376, per the Hon. A. Warrack, Minister of Utilities and Telephones.

148. Id.

149. Id

150. In the Matter of an Application under section 16 of the (Gas Utilities Act) for a change in rates or charges for the supply of gas under a contract. 
sideration of those applications was cut short by the amendment; the "present status [remained] unchanged". Since May, 1976, the Board has not exercised its jurisdiction to fix gas prices under Part 1 of the Gas Utilities Act.

The Board's role in the new gas pricing regime was extended in other ways, however. It sits on appeal from the Alberta Petroleum Marketing Commission in matters concerning a determination of the Alberta cost of service. ${ }^{151}$ It certifies that the price paid for gas supply is just and reasonable in the case of applications for a natural gas rebate. ${ }^{152}$ The Board's continuing jurisdiction to determine complaints against transmission charges has gained in significance due to the current gas pricing mechanism. ${ }^{153}$

In 1975, the Public Utilities Board Act was amended to provide for declarations of exemption regarding certain types of pubic utilities. ${ }^{154}$ The new section reads:

(1) The Board, either upon its own initiative or upon the application of any person having an interest, may, and upon the order of the Lieutenant Governor in Council shall,

(a) declare any of the items referred to in section 2, clause (j), subclause (i), (ii) or (iii) not to be a public utility, or

(b) declare that a provision or any section of this Act is not to apply in respect of any public utility referred to in section 2 , clause (j), subclause (i), (ii) or (iii) or to an owner of such public utility and for so long as the declaration remains unrevoked by the Board the provision therein mentioned has no application in respect of the public utility so designated therein or to the owner of the public utility as such.

(2) An order of the Board under subsection (1) shall be subject to such terms and conditions as the Board may require or which the Lieutenant Governor in Council may impose in an order under subsection (1).

(3) The Board, either upon its own initiative or upon the application of any person having an interest, may after notice and hearing, and upon the order of the Lieutenant Governor in Council shall, vary or rescind in whole or in part any order made by the Board pursuant to this section.

Sections $2(j)(i)$, (ii) and (iii) referred to the definition of "public utility" as meaning, respectively, a telephone system, a railway system and a system for "production ... of water, heat, light or power". Although the stated purpose of the amendment was to give to owners of public utilities the same relief as was afforded to owners of gas utilities, ${ }^{155}$ the exempting power was extended both to the Board and to the Lieutenant Governor in Council, which was an innovation. The Gas Utilities Act was not, at that time, brought into conformity with the Public Utilities Board Act.

Five years passed before any more significant changes were made. Then, in 1980, both Acts were amended in such a way as to extend not only the Board's declaratory powers to exempt, but also the effect of such declarations. ${ }^{156}$ The new declaratory section in the Gas Utilities Act now reads:

(1) The Board, upon its own initiative or upon the application of a person having an interest, may, or upon the order the Lieutenant Governor in Council shall, declare

151. Natural Gas Pricing Agreement Act, R.S.A. 1980, c. N-4, s. 8.

152. Alta. Reg. 174/74 as am., promulgated pursuant to the Natural Gas Rebates Act, R.S.A. 1980 , c. N-5 (originally S.A. 1974, c. 44).

153. See McDill, supra, n. 141 at 130-131. The Board's jurisdiction arises out of ss. 37(2), (3) and (4) of Nova, An Alberta Corporation Act, R.S.A. 1980, c. N-12.

154. S.A. 1975 (2nd session), c. 75.

155. Alberta Hansard, 1975 at 1277-1283.

156. The Public Utilities Board Amendment Act, S.A. 1980, c. 42 and The Gas Utilities Amendment Act, S.A.1980, c. 21. 
(a) that any thing that is a gas utility by virtue of section 2(f)(i), (ii) or (iii) is not a gas utility,

(b) that a person is not for the purposes of this Act an owner of a gas utility, or

(c) that a provision of this Act does not apply to

(i) a gas utility,

(ii) an owner of a gas utility, or

(iii) gas or gas services offered or provided by the gas utility.

(2) During the time that a declaration made under subsection (1)(c) remains in force, the provision in respect of which that declaration was made does not apply, as the case may be, to

(a) the gas utility,

(b) the owner of the gas utility, or

(c) gas or gas services offered or provided by the gas utility.

(3) An order of the Board made under subsection (1) shall be subject to those terms and conditions prescribed by the Board or imposed by an order of the Lieutenant Governor in Council.

(4) The Board,

(a) on its own initiative or on the application of a person having an interest, may, after giving notice and conducting a hearing, or

(b) on the order of the Lieutenant Governor in Council, shall

vary or rescind in whole or in part an order made by the Board under this section.

The new section in the Public Utilities Board Act reads the same, except that the references were to a "public utility by virtue of section $2(j)(i)$, (ii) or (iii)", an "owner of a public utility" and a "public utility".

The statutory exemptions were also extended in both Acts by adding the words "or was not required to be approved by the Board by reason of an existing declaration" to sections 24(2) and 87(2), respectively. As a result of this amendment, an owner was no longer required to obtain specific approval of an issue, trust deed or other instrument or security pursuant to which optional rights of conversion or enforcement proceedings might later be exercised..$^{157}$

The Gas Utilities Act was amended in one other particular: the Act was no longer to apply "to every person owning or operating a gas utility to which the jurisdiction of the Province extends". Instead it was to apply "to every owner of a gas utility". ${ }^{158}$ These amendments were incorporated into the 1980 Revised Statutes of Alberta. ${ }^{160}$ To date, the only other statutory amendments which have been passed affect the Public Utilities Board Act. ${ }^{160}$ The definition of "public utility" has been extended to include "any service that is provided principally through telecommunications"; the definition of "telecommunication" has been extended; and the Lieutenant Governor in Council has been given authority to make regula-

157. Alberta Hansard, 1980 at 387-389. At second reading, the purpose of the amendments was stated to be clarification and consistency.

158. S.A. 1980, c. 21, s. 4. This change received no comment during legislative debate.

159. The relevant sections are now numbered as follows: Public Utilities Board Act, R.S.A. 1980, c. P-37, ss. 1(h) and (j), 70, 71, 91(1)(e) and (h), 91(2) and 92; Gas Utilities Act, R.S.A. 1980 , c. G-4, ss. $1(\mathrm{~g})$ and $(\mathrm{j}), 3,4,25(1)(\mathrm{e})$ and $(\mathrm{h}), 25(2)$ and 26.

160. S.A. 1981, c. 35. Other recent amendments include: The Electric Energy Marketing Act: proclaimed on April 15, 1982. It extends s. 70 of the Public Utilities Board Act by applying ss. 79 to 87,93 and 94 to a municipally owned public utility to the extent that it is "upstream", and it also extends ss. 82 and 83, rate fixing sections, to take into account "upstream" facilities and activities. Bill 40, the Public Utilities Board Amendment Act, 1982 ; assented to on May 4,1982, changes certain administrative provisions having to do with the number of Board members, the length of their tenure, etc. and it clarifies certain references in other sections. It also amends the section regarding licensing regulations by deleting the words "in Alberta" from s. 90.1(1)(a) and by changing s. 90.1(1)(g) to read "governing the information to be given to the issuer of the licence by a licensee from time to time". The Regional Municipal Services Act, yet to be proclaimed, contains other consequential amendments. 
tions regarding the licensing of owners of public utilities. "[T]he intent of the amendment is to change the definition of a public utility to include what in constitutional language might be called an intraprovincial telecommunications undertaking, and provides that the LieutenantGovernor may pass regulations in order to provide for licensing of such telecommunications undertakings." 161 "The purpose here is to fill a void in terms of the province of Alberta exercising an area of constitutional jurisdiction which it has not in the past." ${ }^{112}$

\section{JURISDICTION}

The question inevitably arises: do the Gas Utilities Act and the Public Utilities Board Act really apply to technical owners? ${ }^{163}$ The answer is a qualified yes.

The Board's jurisdiction over technical owners is determined by sections 1 and 4 of the Gas Utilities Act. ${ }^{164}$ The relevant parts of those sections are here set out for ease of reference.

4(1) This Act applies:

(a) to all gas utilities owned or operated by or under the control of a company or corporation that is subject to the legislative authority of Alberta or that has, by virtue of an agreement with a municipality, submitted to the jurisdiction and control of the Board;

(b) subject to subsection (2), to every owner of a gas utility;

(c) to all gas utilities owned or operated by or under the control of the Crown, or an agent of the Crown, in right of Alberta;

(d) to the matters and things set out in Parts 1 and 4 to the extent set out in those Parts.

(2) This act does not apply to a gas utility owned or operated by a municipality unless the gas utility is brought under this Act by a by-law of the municipality as provided in subsections (3) and (4).

\section{Section 70(1)(b) of the Public Utilities Board Act reads:}

subject to subsection (2), to every person owning or operating a public utility to which the jurisdiction of the Legislature extends.

The definition sections relating to "owner", "gas utility" and "public utility" (sections 1) read as follows:

(j) 'owner of a gas utility' means

(i) a person owning, operating, managing or controlling a gas utility and whose business and operations are subject to the legislative authority of Alberta, and the lessees, trustees, liquidators of it or any receivers of it appointed by any court, but

(ii) does not include a municipality that has not voluntarily come under this Act in the manner provided by section 4;

(g) 'gas utility' means

(i) any gas pipeline,

(ii) any system, works, plant, pipes, equipment or service for the production, gathering, conveying, transmission, transporting, delivery, furnishing or supplying of gas by retail or wholesale, either directly or indirectly, to or for the public or any member of the public, whether an individual or a corporation, other than the transportation, delivery, furnishing or supplying by retail or wholesale, either directly or indirectly, of liquefied petroleum gas (except propane and butanes) by means of tank car, tank wagon, cylinder or vessel,

(iii) any absorption plant or scrubbing plant, and

161. Alberta Hansard, 1981 at 480 , per Mr. Knaak at first reading.

162. Id. at 933 (second reading).

163. The question: should the Acts apply to technical owners? is discussed under the heading "Legislative Amendment", infra.

164. And by ss. 1 and 70 of the Public Utilities Board Act. Because the sections are virtually identical, the text has been simplified by making reference only to the Gas Utilities Act except where actual differences exist between the two statutes. References are to the 1980 Revised Statutes of Alberta unless otherwise stated. 
(iv) any system, well, works, plant, equipment or service for the production of gas or capable of producing gas which may be declared by the Energy Resources Conservation Board to be a gas utility;

(h) 'public utility' means

(i) a system, works, plant, equipment or service for the conveyance of telecommunications,

(i.1) any service that is provided principally through telecommunications,

(ii) a system, works, plant, equipment or service for the conveyance of travellers or goods over a railway, street railway or tramway,

(iii) a system, works, plant, equipment or service for the production, transmission, delivery or furnishing of water, heat, light or power, either directly or indirectly, to or for the public, and

(iv) an oil pipeline the proprietor of which may be declared by the Energy Resources Conservation Board to be a common carrier; ${ }^{105}$

To establish jurisdiction, two questions must be answered, namely: to what and to whom does the legislative authority of Alberta extend; and what is a gas or a public utility?

\section{A. Legislative Authority}

Fundamental to the scheme of the Act is a distinction drawn between a thing which is a gas utility and a person who is the owner of it. The distinction would not be too troublesome were it not for certain anomalies and ambiguities and the nebulous nature of the phrase "subject to the legislative authority of Alberta".

Starting out, it seems fairly clear that the Gas Utilities Act applies if there exists

(a) a gas utility which is owned or operated by a person subject to the legislative authority of Alberta;

(b) a person whose business and operations are subject to the legislative authority of Alberta and who owns, operates, manages or controls a gas utility.

There are subtle differences here. In the first case, the gas utility need only be owned or operated. Moreover, it is the person itself who must be subject to the legislative authority of Alberta. In the second case, it is the person's business and operations which must be subject to the legislative authority of Alberta, rather than the person, and the gas utility not only may be owned or operated, it may also be managed or controlled. The case is further complicated by the Public Utilities Board Act. Under this Act, case one is the same, but case two (section $70(1)(b)$ ) requires a person to own or operate (not manage or control) a public utility which itself is subject to the legislative authority of Alberta. ${ }^{186}$ When the operative provisions of the Act are read, however, one must refer back to the definition of an "owner of a public utility" and so once again it is required that there be a person whose business and operations are subject to the legislative authority of Alberta, and who owns, operates, manages or controls a public utility. One is tempted to expostulate!

As a matter of legislative draftsmanship, it seems reasonable to assert control over the person rather than the thing. Short of owning the thing itself, the Legislature has no other means of controlling the manner in

165. The Acts also provide definitions of the following words: absorption plant; butanes; gas; gas pipeline; oil; propane; scrubbing plant; municipality; oil pipeline; and telecom. munication.

166. S.70(1)(b) was not amended in 1980 when s. 4(1)(b) was altered to read, simply, "owner of a gas utility". The latter had formerly read the same as s. 70(1)(b). The Gas Utilities Amendment Act, S.A. 1980, c. 21 became effective May 22, 1980. At that time, the Board had yet to issue its decision on the Telecommunications Inquiry. Whether there is any connection is a moot point. 
which gas utilities are operated. Trouble comes about because it is not always clear just what nexus is meant to exist between the thing or the person and the jurisdiction to which they are to be subjected. In some instances, the definitions of the thing itself provide clarification. Thus, references to "an arrangement of pipes wholly within Alberta" or to the Energy Resources Conservation Board would explicitly limit the Act's purview. The definition of "telecommunications" implicitly limits it, especially having regard to Hansard as an interpretive aid. ${ }^{167}$ In other instances, one is left to struggle with the nebulous phrase "subject to the legislative authority of Alberta" and with a distinction (between a person and its business and operations) which may be without a difference.

The courts have, from time to time, had occasion to construe provincial legislation challenged on the grounds that it was beyond the constitutional competence of a legislature. In so doing, they have demonstrated an inclination to interpret provincial legislation so as to preserve its constitutional validity insofar as this is consistent with the application of principles of statutory construction. In A.G. Ontario v. Reciprocal Insurers, ${ }^{188}$ for example, Duff, J. stated:

...the terms of the statute as a whole are, in their Lordships' judgment, capable of receiving a meaning according to which its provisions, whether enabling or prohibitive, apply only to persons and acts within the territorial jurisdiction of the Province. In their opinion it ought to be interpreted in consonance with the presumption which imputes to the Legislature an intention of limiting the direct operation of its enactments to such persons and acts.

While it has been judicially recognized that a province is competent to regulate the conduct of a particular trade or business in the province, ${ }^{169}$ and that almost any valid provincial statute affecting an industry engaged in extra-provincial trade will have an extra-provincial effect, ${ }^{170}$ it has also been held that there is a territorial limitation on provincial jurisdiction to this extent: if it aims at precluding the satisfaction of rights which have arisen and are enforceable outside the province, the legislation will be ultra vires. The key word is "aims". A statute, which in pith and substance is intended to have an adverse effect on extra-provincial rights, will be struck down.

Royal Bank of Canada v. The Queen, ${ }^{171}$ a case of some relevance to public utilities in Alberta, clearly established this principle. Certain railway promoters had raised funds by way of a bond issue for the purpose of financing construction of the Alberta and Great Waterways Railway Co. The Government of Alberta had guaranteed the bonds which were

167. Alberta Hansard, 1981 at 480 and 933 . See "Legislative History", supra.

168. [1924] A.C. 328 at 354 (P.C.).

169. Citizens Insurance Co. v. Parsons (1881) 7 A.C. 96 (P.C.).

170. Carnation Company v. Quebec Agricultural Marketing Board (1968) 67 D.L.R. (2d) 1 (S.C.C.).

171. (1913) 9 D.L.R. 337 (P.C.). The case was followed by Credit Foncier Franco-Canadian v. Ross [1937] 3 D.L.R. 365 (Alta. App. Div.). See also Ottawa Valley Power Co. v. A.G. Ontario [1936]4 D.L.R. 594 (Ont. C.A.); Beauharnois Light, Heat and Power Co. v. Hydro Electric Power Commission [1937] 3 D.L.R. 458 (Ont. C.A.), Ladore v. Bennett [1939] A.C. 468 (P.C.); A.G. Ontario v. Scott [1956] S.C.R. 137 at 149; B.C. Power Corporation Ltd. v. A.G.B.C. (1963) 47 D.L.R. (2d) 633 (B.C.C.A.); Interprovincial Co-op Ltd. v. Dryden Chemical [1976] 1 S.C.R. 477 at 603-505. 
held by creditors outside the province. As the Lord Chancellor said: ${ }^{172}$

There appears to have been some public uneasiness about the action of the Government ... in the event, a Royal Commission of inquiry was appointed. While it was sitting, there was a change of Government.

The railway promoters defaulted in payment of bond interest and in construction of the railway. The Legislature then sought, by statute, to appropriate to the Province the proceeds of the bond issue. The bond holders sued to retrieve their funds from the bank's Montreal head office where they were held on deposit. They succeeded; it was held that a province cannot legislate to destroy a legal obligation which accrued and was enforceable outside the province. The Public Utilities Act was enacted by the government two years later.

The courts, it appears, will look at the likely effect of legislation to determine its pith and substance. As stated by Locke J. in Texada Mines v. A.G.B.C.: .173 $^{2}$

The true nature of this legislation is not to be determined alone from the language of the statute ... the history of each of these statutes and evidence as to the effect of the legislation upon iron mining in the province may properly be considered in determining what is its true nature.

The history of the Gas Utilities Act and the Public Utilities Board Act would seem to demonstrate that the statutes aim to regulate the natural gas industry for the benefit of the Alberta public. The legislation's true nature is "protection of the provincial consumer."

As to the difference between a person who is subject to the legislative authority of Alberta and a person's business and operations which are so subject, it is to be noted that the statutes draw a further distinction between a "person" on the one hand and a "company or corporation" on the other. The latter reference is to be found in section 4(1)(a) of the Gas Utilities Act which has its genesis in the 1915 Public Utilities Act. Presumably, the Act does not apply to a gas utility owned or operated by an individual but it does apply to the individual if he or she is the owner of a gas utility. This curious anomaly ${ }^{175}$ may have no significance other than as an example of historical happenstance. Perhaps a clue to its origin may be found in an examination of "An Ordinance respecting Water, Gas, Electric and Telephone Companies." 178 This Ordinance, in force in 1915, governed the conduct of utility companies in their relations with municipalities and customers. Nowhere is it stated therein that an individual is precluded from owning and operating a public utility but sec-

172. (1913) 9 D.L.R. 337 at 342 (P.C.). See also J. G. MacGregor, $A$ History of $A$ lberta, (1981) at 210-211. Mr. MacGregor's version is a little more fulsome:

... when the election of 1909 took place, Premier Rutherford's sane government, combined with his appealing policy with respect to the spread of railway lines, swept his party back into power to the tune of thirty-seven Liberals out of forty-one elected members. One of the opposition members, however, was R.B. Bennett, the Conservative from Calgary, who put an end to the hitherto placid administration of the prov. ince's affairs by letting loose a tirade against suspected graft in connection with the Alberta and Great Waterways Railway.

173. [1960] S.C.R. 713 at 718.

174. Dome Petroleum Ltd. v. Public Utilities Board et al (1977) 2 A.R. 453 at 460 (Alta. App. Div.) per Sinclair, J.A.

175. The same anomaly arises in connection with the sections regarding transfer of more than $50 \%$ of an Alberta corporation's shares, wherein it is stated that "if the result of the sale ... would be to vest in the other corporation more than $50 \%$..." These sections also originated in the 1915 statute.

176. Ordinance of the Northwest Territories, 1901, c. 21 as am. 
tion 14 does provide that the Ordinance "shall not prevent any person from constructing any works for the supply of gas, water or electricity or for a telephone system to or on his own premises". All the other sections refer to "the company" or "a company". It may be reasonable to draw the inference that, in 1915, there was no known instance in which a gas utility was owned and operated by an individual. Certainly, all of the major gas utilities during this period were owned and operated by corporations, including the gas utility which supplied Calgary with gas manufactured from coal before natural gas was readily available. ${ }^{177}$

The definition of "owner of a gas utility" was considered by the Alberta Court of Appeal in Re Atco Ltd. and Calgary Power Ltd. et al. ${ }^{178}$ The comments of Clement J.A. are pertinent:

The language used in the statute is, in my view, language which is intended to cover the business and financial affairs of those in the business of a public utilities and as well the exercise by the Board of its powers and jurisdictions over those matters. It should receive the fair, large and liberal construction and interpretation prescribed by the Interpretation Act. The descriptive words in the definition of owner are stated disjunctively and in my opinion are to be interpreted so as best to serve the legislative purpose in the light of the many jurisdictions and powers with which the Board is vested. A person may own a public utility as defined, but not operate or manage it. It will depend on circumstances whether he exercises control. Another may ostensibly operate and manage a public utility, but himself be under the control and direction of another, to carry out specific policies and attain specific objectives. The control may be by means of a conduit of descending and branching flow of residual but effective power. Control is not defined by the statute, and in operation may be protean. Its meaning in the context of a public utilities Act should not be narrowly legalistic, but rather should accord with the realities of control not only in the simple case, but in the present-day pronounced trend towards conglomerates both national and international, corporate diversification, acquisition by take-over bids, and the like. The ramifications behind such corporate activity cannot be ignored.

... control is not to be confined in its meaning to immediate ostensible control of the operation and management of a public utility. In its context the word 'controlling' must be accorded a more comprehensive meaning extending to the operational realities of control for public utilities purposes. There are two factors to be taken into account, neither of which can be treated as in a vacuum. One is the capability of control in the end result. This factor will in some cases involve legal considerations such as shareholder control. The other factor is the exercise of such control. This will normally be a question of fact to be determined by the Board on evidence.

On November 2,1982, the Supreme Court of Canada issued its (as yet unreported) judgement on appeal from the Alberta Court of Appeal Atco decision. A four to three majority of the Supreme Court, led by Estey J., concurred in the comments of Clement J.A. to the effect that the word "controlling" must be given a broad interpretation in the context of the Gas Utilities Act and the Public Utilities Board Act.

\section{B. Gas or Public Utility}

The second question which must be answered in order to establish jurisdiction is, what is a gas utility or a public utility?

The definitions are somewhat cumbersome, but they demonstrate a certain consistency to the extent that three constituent elements are common to all definitions. Physical facilities, an activity using the facilities and a commodity are essential ingredients of each definition. Other factors are not uniformly applied. In two cases, the public is mentioned as consumer or beneficiary; ${ }^{19}$ in two others, the words "travellers" or "common carrier" connote much the same thing. ${ }^{180}$ On the other hand,

177. Calgary Gas Co. Ltd., as described by Gould, id. n. 45 at 60 .

178. (1980) 24 A.R. 300, 320 and 322 (Alta. C.A.).

179. S. 1(g)(ii) Gas Utilities Act and s. 1(i)(ii) Public Utilities Board Act.

180. Ss. 1(i)ii) and (iv) Public Utilities Board Act. 
direct recepton by the general public ${ }^{181}$ and ultimate consumers ${ }^{182}$ is explicitly excluded in two cases. Another factor, the potential declaration by a separate tribunal, is introduced only twice. ${ }^{199}$ A part from the physical facilities used in an activity involving a particular commodity, there is no unifying theme, unless one can found an argument in pubic policy.

Facilities, activities and commodities are classic ingredients in any operation commonly regarded as a public utility, but, as Bonbright said:184

...public utility companies are essentially transportation or transmission agencies. The technology of electric, gas, or telephonic transmission is such as to require a close connection between the plant on the one hand and the consumers' homes or factories on the other. This is even true, though less rigidly so, for a railroad plant. Not all forms of transportation are so strictly localized - not ocean shipping, for example, nor truck transport. But for this very reason, these two forms of transportation have a less well established utility status.

Transportation and transmission, however, are not the common theme of the four definitions of "gas utility" in the Alberta statue. If any sense is to be made of this term, a different rationale must be found.

One of the first observations that can be made is the fact that the activities deemed sufficient to confer gas utility status in clauses (ii) and (iv) of section $1(\mathrm{~g})$ overlap one another. The former contains the words "...production, gathering, conveying, transmission, transporting, delivery, furnishing or supplying...", while the latter contains these words: "...production ... or capable of producing ..." Moreover, the facilities deemed sufficient to confer gas utility status in these two provisions also overlap. The former contains the words "any system, works, plant, pipes, equipment or service...", while the latter contains the words "any system, well, works, plant, equipment or service ...". It can be argued that the rule, expressio unius exclusio alterius, is applicable to these provisions. The rule can be stated thus: ${ }^{185}$

where a statute uses two words or expressions, one of which generally includes the other, the more general term is taken in a sense excluding the less general one: otherwise there would have been little point in using the latter as well as the former

There would seem little point in using clause (iv) as well as clause (ii) unless the Legislature had intended a well to be a special type of gas utility. That it is a special case is corroborated by inclusion in the clause of a special requirement: the Energy Resources Conservation Board's declaration that the facility be a gas utility. ${ }^{186}$ It can be taken, then, that there is a particular type of gas utility having to do with gas wells and well-head operations, and that this type of gas utility is not included in the other three definitions.

181. Ss. 1(i)(i) and (i.1) Public Utilities Board Act, because of the definition of "telecommunication".

182. S. 1(g)(i) Gas Utilities Act, because of the definition of "gas pipeline".

183. Ss. 1(g) (iv) Gas Utilities Act and 1(i)(iv) Public Utilities Board Act: "which may be declared by the Energy Resources Conservation Board...."

184. Id. n. 6 at 13.

185. Maxwell on The Interpretation of Statutes (12th ed., 1969) at 293.

186. No other statutory authority for the E.R.C.B. to declare a facility to be a gas utility has been found. The E.R.C.B. has specific jurisdiction to make common carrier, common purchaser and common processor declarations (Oil and Gas Conservation Act, R.S.A.1980, c. $0-5$, ss. 37-43), but nothing specifically relating to gas utility declarations. S. 23(2), Interpretation Act, R.S.A.1980, c. I-7, may be sufficient: "If in an enactment power is given to a person to do ... any act ... all other powers that are necessary to enable the person to do... . the act ... shall be deemed to be given also". 
Logically, the other three definitions would refer to subsequent links in the chain from well-head to ultimate consumer. A gas pipeline would transport the commodity to an absorption or scrubbing plant and then onwards, but not to the ultimate consumer. At some point or points, the fourth definition would come into play, when gas is delivered or supplied "directly or indirectly to or for the public." This view is bolstered by the fact that clause (ii), when first introduced in 1941, included the words: ${ }^{187}$

$\ldots$ and whether the gas is delivered, furnished or supplied to the public or any member of the public either before or after it has been so treated, processed, purified or scrubbed.

At least in its original intent, the legislation would appear to have distinguished between four different classes of gas utility which span the entire process from production to consumption. It has been held, however, that the facilities comprising a gas utility do not need to be in use in order to come within the purview of the Act. A mere capability to conduct the activities specified by the definitions is sufficient to establish utility status. ${ }^{188}$

Particular problems arise in the interpretation of "gas utility" when the word "service" is considered in the context of a phrase such as "system, works, plant, equipment or service". Ordinarily, the word "service" connotes labour, though its meaning certainly varies with the context in which it is used. The Gas Utilities Act has introduced "service" in conjunction with other terms, all of which connote physical facilities at least to some degree. "System", while it could be something purely physical, need not be restricted to that sense. On the whole, however, it would seem more sensible to construe "service" as some sort of work associated with the physical facilities comprising the gas utility. Driedger makes the point this way: ${ }^{189}$

One ordinary principle of language is that the meaning of a word is influenced by the words with which it is associated.

'English words derive colour from those which surround them. Sentences are not mere collections of words to be taken out of the sentence, defined separately by reference to the dictionary or decided cases, and then put back again into the sentence with the meaning which you have assigned to them as separate words, so as to give the sentence or phrase a meaning which as a sentence or phrase it cannot bear without distortion of the English language'

This principle is sometimes called noscitur a sociis.

The argument is often made that technical owners are not serving the public as such and therefore are not carrying on the sort of activity which is contemplated by the Acts as a proper subject of regulation. Certainly this has been recognized by the Board in its current Guidelines and by the Government on at least one occasion, namely during debate on the 1976 Gas Utilities Amendment Act. ${ }^{190}$ However, the definitions do not uni-

187. S.A. 1941, c. 55, s. 2(iv) was introduced by the same amendment. Both clauses were amended by S.A. 1949, (2nd sess.), c. 8. At that time, clause (ii) lost the words quoted above; and the declaratory power by the E.R.C.B.'s predecessor was added to clause (iv). See "Legislative History", supra.

188. Northern Alberta Natural Gas Development Co. Ltd. v. Edmonton [1921]1 W.W.R. 655 (S.C.C.), per Anglin, J. at 660.

189. The Construction of Statutes (1974) at 85, quoting Stamp, J. in Bourne v. Norwich Crematorium Ltd. [1967] 2 All E.R. 576 (Ch. D.). See also two of the 14 definitions of "service" in The Concise Oxford Dictionary (6th ed., 1976): "System of trains, steamers, buses, etc. plying at stated times" and "Provision of what is necessary for due maintenance of thing or operation." But this interpretation may not apply to the new definition of a public utility as "any service that is provided principally through telecommunications."

190. See supra, under headings "Difficulties in Practice" and "Legislative History". 
formly require that an element of service to the public as such be present. A gas pipeline, for example, explicitly excludes service to ultimate consumers. It is defined as "a pipe or any system or arrangement of pipes ... whereby gas is conveyed from a well-head or other place at which it is produced to any other place... but does not include any pipe or any system ... of pipes ... for the distribution of gas to ultimate consumers". Similarly, an absorption plant and a scrubbing plant do not require public service. The Legislature is competent to confer utility status on any enterprise considered to be of sufficient public importance and necessity as to warrant regulation. From the history of natural gas regulation in Alberta, it is clear that such a policy decision was made long ago.

The Ajax case should be mentioned, as the Alberta Court of Appeal therein determined that: ${ }^{191}$

where a pipeline is not a monopoly and serves one customer it would require very plain words to convert it into a public utility.

Ajax Petroleum Limited had contracted to supply a chemical company with natural gas to manufacture chemicals and textiles. Its subsidiary, Ajax Alberta Pipelines Limited, built a pipeline dedicated to that purpose. Ajax Alberta applied to the Board for a rate increase and the chemical company challenged the Board's jurisdiction on the grounds that Ajax Alberta was not a proprietor of a public utility. The definition of gas pipeline did not apply, since the chemical company was an ultimate consumer. The case was decided on the question of whether A jax Alberta was supplying gas "by retail or wholesale, either directly or indirectly, to or for the public or any member of the public". The Court was of the opinion that "the words 'member of the public' are not apt to describe a corporation," and held that Ajax Alberta was not subject to the Public Utilities Act. The Government's response, three years later, was to amend the definition to read "any member of the public, whether an individual or a corporation". ${ }^{192}$ The apparent legislative intention was to maintain control over all aspects of the natural gas industry. It is useful to remember the comments of Sinclair J.A. speaking for the Alberta Court of Appeal in 1977: $:^{193}$

The protection of the provincial consumer is a primordial element in the scheme of Alberta legislation relating to natural gas and its components.

The two definitions referring to declarations by the Energy Resources Conservation Board contain the words "may be declared". This raises pernicious problems when read in conjunction with section 25(2)(c) of the Interpretation Act. ${ }^{194}$ The section provides that the words "may be" are to be construed as permissive unless the context otherwise requires. The words "may be" first emerged in 1960 when the Gas Utilities Act and the Public Utilities Board Act were introduced. ${ }^{195}$ They have unnecessarily extended the meaning of "gas utility" and "public utility" for it is unlikely that the Legislature intended that a mere potentiality is to be regulated. One would hope that common sense will prevail if there is ever to be a

191. Ajax Alberta Pipeline Ltd. v. Canadian Chemical Company Ltd. (1954) 14 W.W.R.193 at 201.

192. S.A. 1957, c. 75.

193. Dome Petroleum Ltd. v. Public Utilities Board (1977) 2 A.R. 453 at 460 . Quoted with favour in the Atco case, supra, n. 178.

194. R.S.A. 1980, c. I-7.

195. See "Legislative History", supra. 
judicial interpretation of these definitions; in the meantime, a literal interpretation produces the result that any well producing or capable of producing gas and any oil pipeline must be considered, ex hypothesi, a gas utility and a public utility respectively.

\section{Summation}

It is difficult, and dangerous, to answer the question posed at the beginning of this section in the absence of any factual focus, (that is, do the Acts really apply to technical owners?) Much depends in each case on the particular circumstances and the particular characteristics relating to a technical owner. One might conclude, however, that the abundance of caution exercised by legal counsel acting on transactions involving a technical owner is neither excessive nor obsessive. This is apparent from the following observations: The statutes appear to apply to any person doing business in the province of Alberta as it relates to a gas utility in Alberta. The person doing the business need not have actual ownership of the gas utility itself; "operational realities of control" may extend to parent companies. A gas utility may be almost any facility, whether in use or not, that forms a link in the chain from well-head to consumer. It does not appear to be necessary for a person to be serving more than one, let alone many, customers before utility status is conferred. In short, the Acts have wide application indeed.

\section{OTHER LEGAL ISSUES}

If jurisdiction is established, then what is the extent of the jurisdiction? Sections 25(1)(e) and (h), 25(2) and 26 of the Gas Utilities Act delineate the parameters of the Board's jurisdiction regarding financing and disposition approvals. ${ }^{196}$ They are here set out for ease of reference:

25(1) No owner of a gas utility shall

(e) issue any

(i) of its shares or stock, or

(ii) bonds or other evidence of indebtedness, payable in more than one year from the date of them,

unless it has first satisfied the Board that the proposed issue is to be made in accordance with law and obtained the approval of the Board of the purposes of the issue and an order of the Board authorizing the issue,

(h) without the approval of the Board,

(i) sell, lease, mortgage, or otherwise dispose of or encumber its property, franchises, privileges or rights, or any part thereof, or

(i) merge or consolidate its property, franchises, privileges or rights, or any part thereof, with that of any other owner of a gas utility or public utility within the meaning of the Public Utilities Board Act.

and every sale, lease, mortgage, disposition, encumbrance, merger or consolidation made in contravention of this clause is void and of no effect, but nothing in this clause shall be construed to prevent in any way the sale, lease of other disposition of any of the property of any owner of a gas utility in the ordinary course of his business.

(2) Notwithstanding subsection (1), the approval, authority, permission or consent of the Board is not required in or with respect to

(a) the issue of any shares of its capital stock by an owner of a gas utility under the exercise of any optional right of conversion, attaching to any shares, stocks, bonds, debentures, debenture stock or other evidence of indebtedness, the issue of which has previously been approved by the Board or was not required to be approved by the Board by reason of an existing declaration made under section 3 ,

196. And ss. 91(1)(e) and (h), 91(2) and 92 of the Public Utilities Board Act. Again, for convenience, reference will be made only to the Gas Utilities Act since the two statutes contain virtually identical provisions. 
(b) a right of entry, sale, disposition or other proceedings for the enforcement of a mortgage or charge created by trust deed or other instrument of security, in the enforcement of, or pursuant to, the security thereby constituted or in the exercise of the rights or remedies thereby granted or otherwise available at law, if that trust deed or other instrument or security was approved or authorized by the Board or was not required to be approved or authorized by the Board by reason of an existing declaration made under section 3 , or

(c) the declaration or issuance of a stock dividend by an owner of a gas utility.

26(1) Unless authorized to do so by an order of the Board, the owner of a gas utility incorporated under the laws of Alberta, in this section referred to as the 'Alberta company', shall not sell or make or permit to be made on its books any transfer of any share or shares of its capital stock

(a) to any other owner of a gas utility or public utility, within the meaning of the Public Utilities Board Act, or

(b) to any other corporation, however incorporated,

if the result of the sale or transfer, in itself or in connection with other previous sales or transfers, would be to vest in the other corporation more than $50 \%$ of the outstanding capital stock of the Alberta company.

(2) Every purported

(a) assignment or transfer, or

(b) agreement for assignment or transfer,

by or through any person or corporation in contravention of subsection (1) is void and of no effect.

(3) Nothing in subsection (1) shall be construed to prevent the holding of stock lawfully acquired before July $1,1923$.

Classic utility regulation had provided for control of securities, dispositions, encumbrances and mergers ever since it was recognized that rate regulation would be ineffective if the utilities were to be unfettered in their financial dealings. ${ }^{197} \mathrm{~A}$ few examples of the abuses that can be perpetrated may serve to illustrate the rationale for such control. ${ }^{198}$ If "securities are issued upon the basis of fictitious or unsound asset values having no fair relation to the sums invested in or the earning capacity of the properties and upon the basis of paper profits from inter-company transactions", ${ }^{199}$ the utility may require an inordinate earnings stream simply to remain solvent. A sale of a functionally adequate asset acquired when costs were lower than those currently prevailing, and which the utility will be obliged to replace at current cost, could unduly inflate its rate base and consequently its return. A merger between a utility and either a non-utility or another utility can also have an adverse impact on rates or on service, particularly if management attempts to crosssubsidize internal cost centres at the expense of the utility functions.

The rationale for regulatory control of these transactions is prevention of undue financial impact on a utility's revenue requirement which could, in turn, impose an unavoidable necessity for higher rates. Keeping the regulatory rationale in mind, it is proposed to discuss just two aspects of the extent to which the Board has jurisdiction over financing and disposition transactions. The first issue is whether approvals are required prior to entering into a transaction. The second issue has to do with consequences: what happens if the requisite approval or exemption is not in place at the right time? Finally, the subject of exemptions will be addressed.

197. Garfield and Lovejoy, Public Utility Economics (1964) c. 19 and 20.

198. Alberta is an "original cost rate base" jurisdiction. The examples given are to be considered in light of this practice.

199. Public Utility Holding Company Act, 1935 (U.S.) as quoted in Priest, 2 Principles of Public Utility Regulation (1969) at 467. 


\section{A. Prior approval}

The question of prior approval does not arise in connection with securities issues since section 25(1)(e) explicitly requires an owner to "first" satisfy the Board and obtain its approval and authorization. In practice, because many sales and mergers also involve an issue of shares or an issue of evidences of indebtedness payable in more than one year from the date thereof, the transaction will require prior approval in any event. However, if a securities issue is not part of the transaction, then the Act does not stipulate that prior approval is necessary. The point is of some practical significance insofar as the courts have determined that the Board does not have the power to make retroactive orders except in certain limited cases. ${ }^{200}$ If subsequent approval of a sale or a merger or a transfer of more than $50 \%$ of an Alberta corporation's shares were sufficient, some of the difficulties in practice would be eliminated.

The better view seems to be that approval is a condition precedent to effecting a valid sale, merger or transfer. This is so because both section 25(1)(h) and section 26 declare that a transaction completed in contravention of the section is "void and of no effect". ${ }^{201}$ The clear inference is that approval is required prior to the time at which the property passes. ${ }^{202}$

\section{B. Other consequences}

The Act is alarmingly clear when it describes the consequences which follow "every sale, lease, mortgage, disposition, encumbrance, merger or consolidation made in contravention" and "every purported assignment or transfer or agreement for assignment or transfer... in contravention" of sections $25(1)(h)$ and 26 respectively. The Act is silent as to the consequences which follow a securities issue made in contravention of section 25(1)(e) but in view of the fact that a "sale", "mortgage", "disposition" or "encumbrance" may very well encompass an equity or debt issue, the lacuna is not as wide as might first appear.

The law on this subject was summarized by Devlin, J. in the St. John case: ${ }^{203}$

There are two general principles. The first is that a contract which is entered into with the object of committing an illegal act is unenforceable. The application of this principle depends on proof of the intent, at the time the contract was made, to break the law; if the intent is mutual the contract is not enforceable at all, and, if unilateral it is unenforceable at the suit of the party who is proved to have it. ... The second principle is that the court will not enforce a contract which is expressly or impliedly prohibited by statute. If the contract is of this class it does not matter what the intent of the parties is; if the statute prohibits the contract, it is unenforceable whether the parties meant to break the law or not. A significant distinction between the two classes is this. In the former class one has only to look and see what acts the statute prohibits; it does not matter whether or not it prohibits a contract; if a contract is deliberately made to do a prohibited act, that contract will be unenforceable. In the latter case, one has to consider not what acts the statute prohibits, but what contracts it prohibits; but one is not concerned at all with the intent of the parties; if the parties enter into a prohibited contract, that contract is unenforceable.

200. Western Decalta Petroleum Ltd. et al. v. Alberta Public Utilities Board (1978) 9 A.R. 175 (Alta. C.A.). See also Nova v. Amoco Canada Petroleum Co. Ltd. et al. (1981) 32 A.R. 613 (S.C.C.); and Coseka Resources $L$ td. v. Saratoga Processing Co. Ltd. et al. (1981) 31 A.R. 541 (Alta. C.A.).

201. Ss. 91(1)(h) and 92(2) of the Public Utilities Board Act are to the same effect, but state simply that the transactions will be "void" rather than "void and of no effect". The change occurred in the 1980 Revised Statutes.

202. Interesting questions arise in determining "the time at which the property passes." It is beyond the scope of this paper to address such questions, but it is wise to be alert to their possible ramifications.

203. St. John Shipping Corp. v. Joseph Rank Ltd. [1956] 3 All E.R. 683 at 687. 
The Gas Utilities Act declares that a disposition, encumbrance or merger "made" in contravention of this clause is "void and of no effect" and similarly every "purported" assignment, transfer or agreement to assign or transfer more than $50 \%$ of an Alberta corporation's shares is "void and of no effect". The statute prohibits a contract, not its performance. The prohibition is explicit; the contracts are unenforceable regardless of the intention of the parties.

It is more difficult to characterize the effect of the prohibition against issuance of equity or debt securities. The sanction imposed is a fine or imprisonment under the offence sections of the Act. ${ }^{204}$ The word "issue" is not a term of art. ${ }^{205}$ In describing "Issue and Allotment" of shares, the Alberta Corporation Manual describes the formation of a contract as being followed by a share issue ${ }^{206}$ Because of the imprecision with which the word is commonly used and the nature of the penalty imposed, the statutory prohibition in this case probably goes to performance of the contract. Following Devlin J., a debt or equity issue would be unenforceable only as against those contracting parties who had knowledge of the statutory prohibition and who had failed to obtain Board approval. The Picbell ${ }^{207}$ case is an example of such a result. By reason of an Order in Council, the terms of a charter party were required to be submitted "in advance" and approved by the Canadian Shipping Board. The Order in Council provided no procedure for retroactive approval but simply stipulated that "no such charter party as aforesaid shall be made without such approval". Rand, J., speaking for the Court, said::208

Assuming that a binding contract or charter party subject to such a condition could be made, the effect of the regulation was that no performance or execution of it could take place before that approval.

The evidence showed that the charter party was performed from April 10,1946 until April 15, 1950 at which time the respondent repudiated the contract on grounds of illegality. Although the Order in Council had been revoked at the end of 1946, the Court refused to uphold the contract.

There has been a trend, however, to relieve against the draconian effect resulting from strict application of the law. As was stated in Maschinenfabrik Seydelmann K-G. v.Presswood Bros.: ${ }^{209}$

There is at present a tendency to regulate many activities in modern life by statutes or by regulations authorized by statutory enactments, and the distinction between a contract inherently illegal because it cannot be performed without violating the law and one which can be legally performed but is void on the ground that there was an intention to perform it in an illegal manner cannot be disregarded.

Using one device or another, the courts have frequently avoided the full consequences of the rule. At bottom, the cases can be reconciled one to the other on the grounds of public policy or equity. In Patterson v. Burton, ${ }^{210}$ for instance, the Supreme Court of Canada refused to apply the rule in favour of shareholders who were resisting a call on the unpaid balance of their shares. Action was instituted by the liquidator in

204. Ss. 43-47.

205. Anglo-American Lumber Co. v. McLellan (1908) 14 B.C.R. 93 (C.A.).

206. At 3020-3022.

207. Picbell Ltd. v. Pickford \& Black, $L$ td. [1951] S.C.R. 757.

208. Id. at 758.

209. [1966] 1 O.R. 316 at 322 (C.A.).

210. [1950] S.C.R. 578. 
winding-up the corporation. Although it had been established in evidence that the shares had been issued without the Board's certificate under the Alberta Sale of Shares Act, 1922, the Court was clearly of the opinion that it would be inequitable to allow the shareholders to receive the benefits of membership without also assuming the obligations thereof. ${ }^{211}$ Another device used by the courts entails a finding that the statute is designed to protect the public or a particular class of persons. If the party seeking to enforce or to avoid the contract falls within the protected class, the court will rule in his favour. C.M.H.C. v. Co-operative College Residences, Inc. et al $^{212}$ and Anderson $L t d$. v. Danie ${ }^{213}$ are illustrations.

There is no doubt that the Gas Utilities Act and the Public Utilities Board Act have, as their object, protection of the public, but it is a particular public that is protected, namely rate-payers. ${ }^{214}$ The status of the person seeking to enforce or to avoid the contract, and also the circumstances surrounding the defence of statutory illegality, would be factors taken into consideration in determining the enforceability of an equity or debt security.

An argument can be made that these consequences follow only if the disposition or encumbrance is voluntary. If an owner's "property, franchises, privileges or rights" were expropriated, for example, it would seem unreasonable that the expropriating authority could be frustrated by the Board's refusal to grant approval. The Act states that no owner shall dispose of or encumber its property. To dispose of something requires a willingness on the owner's part to alienate his interests and a willingness on the recipient's part to take them. ${ }^{215}$ To encumber something requires that its owner place a charge or a burden against it. ${ }^{216}$

\section{Exemptions}

The Act provides for both "statutory exemptions" (or exclusions) and "declaratory exemptions". "Statutory exemptions" are created by the Acts themselves. Certain transactions have been excluded from the class of transactions requiring Board approval. The statutory exemptions include a "sale, lease or other disposition" (but not an encumbrance or merger) made in the ordinary course of business; a share issue made pursuant to an optional right of conversion attached to a previously approved or exempted security; enforcement proceedings pursued under a previously approved or exempted security; and stock dividends. The "declaratory exemptions" are, of course, those exemptions which the Board is empowered to make under section 3 of the Gas Utilities Act and section 71 of the Public Utilities Board Act. It is proposed to comment briefly on declaratory exemptions.

The Board's powers were extended in $1980 .{ }^{217}$ It can now order that something that would otherwise be a gas utility or a public utility is not

211. R.S.A. 1922, c. 169, s. 4 stated "No person ... shall sell ... any shares ... without first obtaining from the Board [of Public Utility Commissioners] a certificate...". The penalty was by fine or imprisonment. See also "Legislative History", supra.

212. (1975) 13 O.R. 394 (C.A.).

213. [1924] 1 K.B. 138 (C.A.).

214. Rate-payers, of course, could include persons other than ultimate consumers. Processing fees can, arguably, be included in the expression "rates, tolls or charges".

215. Harman v. Gray Campbell Ltd. [1925] 2 D.L.R. 904 (Sask. C.A.).

216. Greene v. Appleton (1915) 25 D.L.R. 333 (Alta. App. Div.).

217. S.A. 1980, c. 21 and c. 42 respectively. See "Legislative History", supra. 
one; ${ }^{218}$ that a person is not an owner for the purpose of the Act; ${ }^{219}$ and that a provision of the Act does not apply to the utility, the owner or "gas or gas services" ("goods or services") offered or provided by the utility. Declaratory powers regarding the owner and the commodity or services are new. Declarations that an owner is not an owner have become particularly popular because such exemptions relieve the owner from all obligations under the statutes, other than those imposed as conditions in a Board order. ${ }^{221}$

Lawyers who require an exemption order for their clients have expressed a great deal of concern about the nature of order granted by the Board. Their concern has, in one way or another, focussed on future effectiveness. Will the exemption order continue to be valid so as to protect an owner from the drastic consequences of future non-compliance with the Acts? There is little point in obtaining an exemption and relying upon it if there is any danger that such reliance will result in a void transaction at some later date. Two questions are at issue here: first, what is the stated term of the order; and second, what is the effect of a breach of condition?

The Acts do not specify what the term of any Board order shall be. The general provisions of the Public Utilities Board Act stipulate when the term begins and what limitations on term the Board is empowered to place, ${ }^{222}$ but if there is to be a termination date, then it is the Board which sets it. Until 1981, the standard form of order provided that it would remain in force until revoked or rescinded by the Board. Apart from a possible conflict between this stated term and the effect of the condition simultaneously imposed (discussed, infra), there was little difficulty. Since 1981, however, the Board's standard form of order states that it is to "remain in full force and effect for so long as" an owner does not "own, operate, manage or control" a gas utility of the type precluded by the order. It is questionable whether the Board has the authority to stipulate such a term. Section 52(1) of the Public Utilities Board Act ${ }^{229}$ provides that "the Board may direct that the whole or any portion of the order have force ... until the happening of any specific event". The "event" which the Board's order attempts to describe is hardly specific. If anything, the

218. Subsections (1)(a). Note that only certain types of gas utility are included - the Board cannot undo an ERCB declaration - and that only certain types of public utility are included - a telecommunication system (but not a telecommunications service), a railway system and a system for production (etc.) of "water, heat, light or power".

219. Subsections (1)(b).

220. Subsections (1Kc).

221. It should be noted in passing that technical owners are not subject only to the financing and disposition sections of the Acts. The full force of the statutes apply to them although, in practice, they are not enforced for the most part if at all. Provisions affecting depreciation and other accounting practices, rates and extension of service would also be ap. plicable if an owner were fully regulated.

222. See particularly ss. 52,54 and 61 . Section 108 would not seem to apply since it refers to orders "to continue service or rates".

223. Subsection (1) of section 52 states that:

The Board may direct in any order that the order, or any portion or provision thereof, come into force

(a) at a future fixed time,

(b) on the happening of a contingency, event or condition specified in the order, or

(c) on the performance, to the satisfaction of the Board or a person named by it for the purpose of any terms that the Board imposes on any party interested,

and the Board may direct that the whole or any portion of the order have force for a limited time or until the happening of any specific event." 
standard form of order describes a status. It is, moreover, a status which can be debated both on fact and in law. The "event" is wholly uncertain and, whether or not the Board can legitimately impose such a termination date, it gives little comfort to a technical owner.

The fact that the standard form of exemption order contains a condition presents even greater problems. If the effect of a breach of such a condition is to void an otherwise valid transaction, the Board has created a situation in which the very purpose of an exemption order has been frustrated.

Since 1975, it has been the consistent practice of the Board to prescribe a condition in its orders. ${ }^{224}$ Regarding orders under subsections (1)(c), an owner is required to report details of securities issues, dispositions, encumbrances and mergers and also to state the nature of its service to the public. Regarding orders under subsections (1)(b), an owner is required to report forthwith if it becomes an owner of certain types of gas utility; essentially this reporting condition also relates to the nature of an owner's service to the public. ${ }^{225}$ These reporting requirements are conditions subsequent. Usually, an administrative tribunal will attach conditions to its orders as prerequisites to its approval, not as continuing obligations.

There is authority to the effect that an administrative tribunal cannot impose a continuing obligation. In Re McGregor, ${ }^{226}$ the Ontario Court of Appeal considered a section of the Ontario Municipal Board Act which is identical to section 52(1) of the Alberta Public Utilities Board Act. The Court concluded that a condition subsequent was beyond the Ontario Board's jurisdiction. However that may be, the balance of this discussion will be based on the tenuous assumption that the Alberta Board's imposition of reporting requirements is a valid exercise of its powers.

The question remains, what is the effect of a breach of the condition? Is the order thereby voided or voidable, or does the breach affect only the transaction which was not reported in a timely fashion?

It is arguable that a breach renders the order voidable at the Board's option rather than void $a b$ initio. The Acts require that the Board give notice and hold a hearing before varying or rescinding an exemption order. ${ }^{227}$ It is inconceivable that an order could fall without the same protection, especially since most if not all failures to comply with the condition are inadvertent. Under the oldest form of condition, the owner was required to report prior to the effective date of a transaction. Compliance was (and is, if any such orders are outstanding) impossible in those circumstances in which a transaction was initiated and completed after the stipulated effective date. Severe inequities could result unless the order were voidable. ${ }^{228}$

It is also arguable, however, that a breach renders the order ineffective

224. See "Difficulties in Practice", supra.

225. The same "event" which is supposed to terminate an exemption order is also supposed to trigger a report to the Board. The same remarks regarding uncertainty of the status or "event" can be directed to this reporting requirement.

226. Re McGregor and Borough of Scarborough [1973] 3 0.R. 429 (C.A.).

227. S. 3(4), Gas Utilities Act and s. 71(4), Public Utilities Board Act.

228. Quaere whether an exercise of a "statutory power" would come into play pursuant to the Administrative Procedures Act, R.S.A. 1980, c. A-2. 
only as it applies to the transaction which was not reported as required. That particular transaction would therefore be void or otherwise unenforceable, although the order would continue in force. Such a result would be much worse than a voidable order. It would be unconscionable to allow a person to hide behind the statutory provisions which void a transaction simply because a technical owner inadvertently passed a reporting deadline. The better practice, of course, would be to avoid stipulating any condition in an exemption order. If an applicant seeking an exemption order were required to undertake to report and subsequently failed to do so, the Board would be free to take whatever action it considers appropriate when it discovers the breach of undertaking. The Acts are, after all, designed to protect rate-payers. A rate-payer in trouble will soon enough alert the Board if there is any abuse of service.

Different arguments might be mustered if there were a procedure whereby the Board could cure defects or correct nullities. There is, however, no retroactive power or other general remedial power which the Board might call in aid unless it is section 55 of the Public Utilities Board Act. That section permits the Board to expand the time specified for the doing, performance or completion of any "work, act, matter or thing". It would be necessary, if this section were to be an effective remedy, first to so construe it as to permit an extension of time after expiry of the otherwise specified time limit. If an analogy can be drawn from In Re Manchester Economic Building Society, ${ }^{229}$ then the Board does have that ability. The case involved a question of whether it was possible to grant leave to appeal after the time prescribed therefor has passed. It was concluded that a rule of court conferring the power to grant leave allowed the court to do so following expiry of the otherwise applicable time limit. By this reasoning, the jurisdiction conferred on the Board by section 55 would encompass the authority to grant an extension of time after the otherwise applicable time limit had expired. In that event, however, there will have been a hiatus during which default has occurred. If the default concerns a transaction which would be void in the absence of approval or exemption, then the transaction would be a nullity anyway. Section 55 therefore does not provide an effective remedy.

\section{LEGISLATIVE AMENDMENT}

The Gas Utilities Act and the Public Utilities Board Act represent a governmental policy statement. With respect to natural gas in Alberta, the government has demonstrated a long standing intention to control every phase of the industry from well-head to consumption within Alberta. The Board's role has been to fix rates, tolls and other charges and, between 1949 and 1975, to fix field prices of natural gas. In 1976, the government clarified its intention regarding the Gas Utilities Act, stating that the Act should apply only with respect to persons supplying gas by what is commonly called a public utility. ${ }^{20} \mathrm{Field}$ prices are now controlled by other means. The Acts, however, continue to apply to what have become known as technical owners. They are subject to financing and disposition approvals that are designed to prevent undue increases in revenue requirements, a concept inherent in classic utility regulation but

229. (1883) 24 Ch. D. 488 (C.A.).

230. Alberta Hansard, 1976 at 1376. See "Legislative History", supra. 
not particularly relevant to or appropriate for the technical owners. The question is: should technical owners continue to be subject to the Board's jurisdiction given the concurrent jurisdiction to control their operations under other statutes? The answer is yes. The constitutional validity of the Natural Gas Pricing Agreement Act (etc.) is much less certain than that of the Gas Utilities Act and the Public Utilities Board Act. ${ }^{291}$

In any event, legislation is in place to relieve technical owners from the worst rigours of utility regulation. Amendments made in 1980, particularly, recognized the need for procedures by which owners can be deregulated in the proper case. The procedures have not been extended far enough, however. Deregulation cannot be fully effective if the contracts formed and performed by technical owners continue to be subject to uncertainties created by the very statutes from which the technical owners have been exempted. The remedy is simple: extend the Board's powers so as to allow it to make retroactive exemption orders. It is not suggested that specific approval orders be given retroactive effect. The power to control securities issues, dispositions, encumbrances and mergers is essential for effective utility regulation. If an owner has been deregulated in whole or in part, however, then there ought to be a procedure whereby its contracts can be perfected, even after a defect or a nullity has been discovered, if it is the Board's opinion that the circumstances warrant the granting of a retroactive exemption order. ${ }^{232}$

One other legislative amendment which is greatly to be desired is equally simple to effect. The words "may be" ought to be replaced by the word "is" in the two clauses which require a declaration by the Energy Resources Conservation Board. ${ }^{233}$ Either the works, well (etc.) have been declared to be a gas utility, in which case they should be regulated by the Public Utilities Board; or they have not been, in which case they presumably are sufficiently controlled by the requirements of other statutes. The same applies to oil pipelines which have or have not been declared to be common carriers.

\section{PRACTICE NOTES}

The best advice that can be given lawyers representing technical owners is this: get an exemption order declaring that an owner is not, for the purposes of the Acts, an owner of a gas or public utility. As matters now stand, an applicant need not actually be an owner. It is sufficient, according to the Board's current Guidelines, if the applicant can give an affidavit to the effect that it "may be or may become" an owner. It is wise to get an exemption from the Public Utilities Board Act as well as from the more obvious Gas Utilities Act because of the definitions of "public utility". "Any service that is provided principally through telecommunications" does not require that an applicant own any apparatus. Communications through mobile telephones and electronic control of pipeline or well activities may qualify as a public utility, and, of course, any oil

231. Elliott, "Jurisdictional Dilemmas in Resource Industries", (1979) 17 Alta. L. Rev. 91; Thring, "Alberta Oil and the Constitution" (1979) 17 Alta L. Rev. 69.

232. S.25(2) of the Gas Utilities Act and s.91(2) of the Public Utilities Board Act would require consequential amendments. The sections refer to certain transactions performed pursuant to a security which "was not required to be approved or authorized by the Board by reason of an existing declaration" made under section 3 or 71 . The reference to "existing" would need to be expanded to include retroactive declarations.

233. S. 1(g)(iv), Gas Utilities Act and s. 1(i)(iv), Public Utilities Board Act. 
pipeline, large or small, literally constitutes a public utility.

As to other suggestions offered on a practical note, reference is made to the hypothetical case studies described earlier in the section "Difficulties in Practice". The case studies will not be discussed in detail; some general comments can be taken to apply where appropriate.

One rather drastic remedy which has been applied, when it is discovered that a Board approval or exemption has not been obtained in time, is re-enactment of an entire closing ceremony. This action presupposes that the first closing was ineffectual. The necessary Board order is therefore obtained and the transaction is thereafter redone in every particular. It may be regarded as absurd that one would be required to go to such lengths to achieve one's goal. Nevertheless, re-closing can be a complete, and is perhaps the only complete answer in certain circumstances.

The case law points out another device which can be used when debt or equity securities are being issued. The contract could be made subject to a condition that the necessary Board order be obtained. Performance of the contract would then be postponed until after the order was in place. ${ }^{234}$ This device would, however, not be effective in the case of a sale, lease, mortgage or other dispositon or encumbrance, of a merger or consolidation or of a transfer or sale of more than $50 \%$ of an Alberta corporation's shares. Therefore, it has little or no practical application.

Regarding amalgamations, the better view seems to be that companies formed by amalgamation require a new exemption order. It is thought that section 180(f) of the Business Corporations Act does not operate to extend to the amalgamated company the protection afforded by an exemption order granted to one or more of the amalgamating companies. Because the amalgamated company does not come into existence until the Registrar of Companies issues a certificate, some lawyers have waited until the amalgamation has taken place before obtaining the exemption order. This practice is not always feasible, however, because the Board does not always accede to a request that a division take the application at that often critical (and short) juncture between amalgamation and subsequent transactions effected by the newly amalgamated company.

Finally, it has been necessary in some cases for a lawyer to give a qualified opinion letter. It is wise, in a case of this sort, for the lawyer to discuss the need for qualification as early as possible in the negotiations so that underwriters, trustees and others have time to consider their position. As an example of the sort of qualification which might be given when a trust indenture contains a "negative pledge", the following is offered:

With respect to the opinions expressed, the obligation of the Company to provide security under Section $\mathrm{X}$ of the Trust Indenture is subject to the qualification that performance of such obligation at the time involved would be in contravention of the Gas Utilities Act (Alberta), if at such date the Company is an owner of a gas utility as defined under such Act, or the Public Utilities Board Act (Alberta), if at such date the Company is an owner of a public utility as defined under such Act, unless

(i) prior to such date an order of the Public Utilities Board of the Province of Alberta has been issued declaring the Company to be exempt from certain provisions of the said Acts; or

(ii) prior to the date such performance is required, the Company has obtained an order under either or both such Acts, as may then be applicable, approving the provision of security and such order or orders are in effect at the applicable time.

234. See Picbell Ltd. v. Pickford \& Black, Ltd. [1951] S.C.R. 757 and Murray Elias Ltd. v. Walsam Investments Ltd. [1964] 2 O.R. 381 (H.L.). 